\title{
EXCHANGE-RATE ECONOMICS FOR THE RESOURCES SECTOR*
}

\author{
by \\ Kenneth Clements, Yihui Lan* and John Roberts \\ UWA Business School \\ The University of Western Australia
}

This version: $30^{\text {th }}$ July 2007

\begin{abstract}
The paper provides an account of aspects of exchange-rate economics that are of particular relevance to the resources sector. The issues discussed include exchange-rate volatility and risk management practices used to deal with it, the role of productivity differences across countries, the impact of a booming resources sector on the country's exchange rate and approaches to forecasting exchange rates. The discussion is organised around a simple stylised model that emphasises the quantity theory of money and purchasing power parity as a long-run link between prices and exchange rates.
\end{abstract}

\footnotetext{
* This research was supported in part by the ARC, ACIL Tasman, AngloGold Ashanti and the WA Department of Industry and Resources. The views expressed herein are not necessarily those of the supporting bodies. We would like to acknowledge the excellent research assistance of Callum Jones.

*Corresponding author: Yihui.Lan@uwa.edu.au.
} 


\section{Introduction}

As resource-based products tend to be intensively traded internationally, producers face high levels of cash flow uncertainty, a major source of which is exchange rate volatility. Since the demise of the Bretton-Woods system of fixed exchange rates in 1973, the major currencies have been floating and an enduring empirical regularity of the behaviour of exchange rates is their short-run volatility. To get an idea about the extent of this variability, consider the behaviour of currencies for three countries -- Britain, Germany and Japan, which have close economic ties, relatively few trade barriers and whose currencies have been more or less freely floating with only minimal government intervention. The left panel of Figure 1 plots the monthly log change of each nominal exchange rate, $\mathrm{S}$, relative to the US dollar. The percentage monthly changes range from -10.4 to 10.7 percent, implying an annual change well over 100 percent, which is obviously huge. The average absolute monthly percentage change is about 2 percent for the three exchange rates, which translates to an annual change of about 24 percent. Clearly, on a month-to-month basis exchange rates are highly volatile; and this volatility would be even higher with daily data.

In addition to the risk-management challenges presented by volatile exchange rates to resources companies, there are at least two other reasons why exchange rates are especially important for the resources sector. First, large-scale resource projects can impose external effects on other sectors of the economy via their impact on the exchange rate. Such projects typically result in a surge of new export revenue, which has the effect of appreciating the country's exchange rate if the surge is substantial. While the appreciation helps the economy adjust to the new project, it still involves the negative externality of hurting other exporters and producers in the import-competing sector. Recent examples include the oil and natural gas boom in Russia, and the current minerals boom being experienced in Australia.

A second reason for the importance of currency values to the resources sector is the workings of so-called “commodity currency model”. For some resource-exporting countries, variations in world commodity prices tend to have a substantial impact on their currency values. These commodity price impacts are over and above the usual purchasing power party effects, and change real exchange rates (that is, price-level adjusted rates). A prominent example of this phenomenon is the Australian dollar, which appreciates when commodity markets (especially those for metals) boom, and depreciates when they crash. The commodity currency model also applies to varying degrees to Canada, New Zealand, South Africa, and a number of smaller developing countries. Research shows that the elasticity of the Australian dollar with respect to commodity prices more 
often than not lies within the range $0.5-0.8 .^{1}$ Supposing for the purposes of illustration that this elasticity is 0.6 , a 10 -percent increase in world commodity prices would then cause the \$A to appreciate in real terms by 6 percent, and Australian-dollar commodity prices to rise by about 10-6 $=4$ percent. Due to these interactions between prices and exchange rates, producers in a country with a commodity currency have a type of natural hedge if they are do not explicitly hedge and remain exposed to both the commodity-price and foreign-exchange risk. The neglect of this sort of interaction between prices and the exchange rate can led to serious error in the forecasts of resource project revenue expressed in domestic-currency terms, and systematic biases in their net present values (NPVs): In particular, NPVs will be overestimated in good times, when commodity prices are high (as the exchange rate will appreciate), and underestimated in tough times (the rate depreciates).

While exchange-rate economics is a controversial area, it is still the case that a substantial body of research now finds that over the longer term exchange rates are "anchored" by price levels. This idea is embodied in purchasing power parity (PPP) theory, which states that the exchange rate is proportional to the ratio of price levels in the two countries. To illustrate, consider the right panel of Figure 1 that uses annual data to plot the exchange rate (relative to the US dollar) of each of three countries, $\mathrm{S}$, and the ratio of their price level to that of the US, $\mathrm{P} / \mathrm{P}^{*}$. A comparison of this panel with the left panel reveals that the use of annual rather than monthly data has the effect of smoothing out many of the short-term fluctuations. Note that British prices increased relative to those in the US over the whole period, while those of Germany and Japan decreased. According to PPP theory, the British pound should depreciate (an increase in S), and the German mark and Japanese yen should appreciate. This is consistent with what in fact happened, as can be seen from the long-term behaviour of exchange rates in the right panel of the figure. Even though the three exchange rates all deviate substantially from $\mathrm{P} / \mathrm{P}^{*}$ at times over the whole 30-year period, a careful examination reveals that in each of the three panels, the price ratio can be interpreted as playing the role of the "underlying trend", or anchor, for the exchange rate. That is to say, while the exchange rate meanders around (above and below) the price ratio, over time it has a distinct tendency to revert to this trend value. While the existence of persistent and large deviations is not consistent with strict PPP, the figure still provides some prime facie evidence in favour of PPP over the long term.

This paper provides an account of aspects of exchange-rate economics that we judge important for the resources sector. We emphasise PPP as a long-run determinant of exchange rates, together with two reasons for significant departures from parity, viz., (i) the role of differential

${ }^{1}$ For references and further details, see Clements and Fry (2006). Substantial research on commodity prices is 
productivity growth across countries, which is known as the "productivity-bias hypothesis"; and (ii) the Dutch disease, which relates to the impact of large resource projects on exchange rates. Because of their particular relevance to the resources sector, we also discuss the nature of and reasons for the short-term volatility of exchange rates, and recent approaches to exchange-rate forecasting. We do not attempt a comprehensive account of the theory of exchange rate determination as that is now a vast area of research, and has been the subject of a number of surveys in recent years, including Frankel and Rose (1995), Froot and Rogoff (1995), Isard (1995), Krugman (1993), Sarno and Taylor (2002), Taylor (1995) and Taylor and Taylor (2004), and Taylor (2006).

The structure of the paper is as follows. Section 2 outlines currency risk management practices of resources companies. Section 3 sets out the core analytical framework in the form of a novel geometric analysis of the relationship among exchange rates, money and prices. We use that framework to study as a base case the effects of monetary shocks in the presence of flexible prices. Section 4 examines exchange-rate overshooting caused by a monetary shock when prices are sticky, whereas Section 5 investigates the impact on exchange rates of an increase in the productivity of a country's traded-goods sector. Section 6 focuses on the characteristics of exchange-rate movements resulting from a booming resources sector, followed in Section 7 by a review of alternative perspectives and evidence on these effects. Recent approaches to exchangerate forecasting are discussed in Section 8. The final section concludes.

\section{Currency Risk Management Practices}

The floating exchange rate regime makes companies in the resources sector vulnerable to risk caused by large currency swings. The uncertainties regarding exchange rates of a company mainly come from (i) the translation of foreign-currency denominated sales into domestic currency; (ii) foreign currency loans; and (iii) competition with producers whose costs are denominated in a foreign currency (Maloney, 1990). High exchange rate volatility usually leads to high cash flow fluctuations and possible financial distress for resources firms. To manage foreign exchange risk and thus lower cash flow fluctuations, firms carry out hedging activities to reduce or eliminate their exposure to exchange rate changes. General speaking, there are two types of hedging, natural hedging and derivatives hedging. The former is the strategy that accounts for net currency exposure on the balance sheet, or as a result of trade, or combination of both, while the latter involves the use of derivatives such as currency forward contracts, currency swaps, currency options, currency futures, etc.

undertaken at the International Monetary Fund; for details, see http://www.imf.org/external/np/res/commod/bib.htm. 
Early in the post-float period, a high proportion of Australian companies with foreign currency exposure were involved in hedging activities, with the average proportion of foreign exchange exposure hedged reaching 70 percent in the 1989/90 (Becker and Fabbro, 2006). Tufano (1996) finds that over 85 percent of gold-mining firms in the US engage in hedging in 1990-1993. But even hedging is not without its own risks and if not handled carefully, can lead to catastrophic results. For example, in 2001, the Australian zinc company Pasminco went bust because its poorly-managed hedging strategy resulted in a \$2.4 billion loss when both zinc prices and \$A were falling. BHP Billiton, the world's largest diversified miner, lost something of the order of half a billion US dollars from currency changes in the financial year 2002-3. ${ }^{2}$ Financial market participants complain of major problems with hedging associated with the lack of transparency and continuous disclosure. In response to unimpressive results from hedging and objections from financial markets, the last few years has seen an ongoing decline in hedging. Using gold as an example, Figure 2 shows that global gold hedging has fallen by as much as 60 percent over the last five years. Other reasons behind what has become known as "the dehedging phenomenon" include rising gold prices and the decrease in interest rates around the world (Cross, 2003). As they become more exposed to foreign exchange risks, dehedging makes it even more essential for resources companies to understand the behavior of exchange rates, their fundamental determinants and exchange rate forecasts.

\section{The Geometry of Exchange Rates, Money and Prices}

In this section, we first set the scene for what is to come by examining the relationship between money and prices in the form of the quantity theory of money. We emphasise aspects of both open and closed monetary economics by drawing the distinction between traded and non-traded sectoral prices that make up the general price level. Next, we add exchange rates to the pricemoney paradigm. Finally, we analyse the effects of monetary shocks on exchange rates in the presence of flexible prices.

The quantity theory of money (QTM) is built on the equation of exchange, which shows the relationship between the money supply, velocity, prices and volume of transactions. ${ }^{3}$ The transactions version of the QTM is $\mathrm{MV}=\mathrm{PT}$, where $\mathrm{M}$ is the supply of money balances, $\mathrm{V}$ is the velocity or rate of circulation of these money balances, $\mathrm{P}$ is the general level of prices of all

\footnotetext{
${ }^{2}$ For details, see “BHP Billiton Preliminary Financial Results for the Year Ended 30 June 2003”, 28 August 2003. Available at http://www.bhpbilliton.com/bbContentRepository/Reports/PPAJune2003.pdf.

${ }^{3}$ The modern version of the quantity theory of money is due to Friedman (1956), who attributes much of what he presents to the "Chicago oral tradition". Like many things associated with Friedman, this attribution is controversial; see Johnson (1971) and Patinkin (1969).
} 
transactions, and $\mathrm{T}$ is the volume of transactions. In many versions of the QTM, $\mathrm{V}$ and $\mathrm{T}$ are fixed, so that an increase in the supply of money will lead to a proportionate increase in the price level, i.e., $\hat{\mathrm{P}}=\hat{\mathrm{M}}$, where a circumflex (“^”) denotes percentage change. Figure 3 shows this relationship and illustrates that a doubling of the money stock leads to a doubling of prices.

The goods that make up the general price level $\mathrm{P}$ can be decomposed into traded and nontraded goods. As implied by the name, the pricing of traded goods is related to world economic conditions, while non-traded goods prices are determined by domestic factors. The price level function is then $\mathrm{P}=\mathrm{P}\left(\mathrm{P}_{\mathrm{T}}, \mathrm{P}_{\mathrm{N}}\right)$, where $\mathrm{P}_{\mathrm{T}}$ and $\mathrm{P}_{\mathrm{N}}$ are prices of traded and nontraded goods, respectively, which we shall refer to as "sectoral prices". An increase in either sectoral price with the other held constant leads to a rise in the overall price level, so that $\partial \mathrm{P} / \partial \mathrm{P}_{\mathrm{T}}>0, \quad \partial \mathrm{P} / \partial \mathrm{P}_{\mathrm{N}}>0$. The price level is plotted as the downward sloping convex curve AA in Figure 4 and is called the "absolute price schedule" along which the price level is a constant.

The price function can be thought of as an "aggregator function”, or a price index. Fisher (1922) evaluates various forms of price indices by their ability to satisfy ten key tests. One such test is proportionality whereby if all prices are multiplied by a positive constant $\lambda$, then the new value of the index should be equal to the old index multiplied by $\lambda$. In other words, the index should be homogeneous of degree one. The price level can be written in terms of proportional changes as

$$
\hat{\mathrm{P}}=\gamma_{\mathrm{T}} \hat{\mathrm{P}}_{\mathrm{T}}+\gamma_{\mathrm{N}} \hat{\mathrm{P}}_{\mathrm{N}}
$$

where $\gamma_{\mathrm{i}}=\partial(\log \mathrm{P}) / \partial\left(\log \mathrm{P}_{\mathrm{i}}\right)$ is the elasticity of price level $\mathrm{P}$ with respect to the price of traded goods $P_{i}(i=T, N)$. Proportionality implies that $\gamma_{i}$ is a positive fraction with $\gamma_{T}+\gamma_{N}=1$. Using $\mathrm{P}=\mathrm{P}\left(\mathrm{P}_{\mathrm{T}}, \mathrm{P}_{\mathrm{N}}\right)$ and $\gamma_{\mathrm{i}}=\left(\partial \mathrm{P} / \partial \mathrm{P}_{\mathrm{i}}\right) \mathrm{P}_{\mathrm{i}} / \mathrm{P}$, the slope of absolute price schedule in Figure 4 is

$$
\left.\frac{\mathrm{dP}_{\mathrm{T}}}{\mathrm{dP}_{\mathrm{N}}}\right|_{\mathrm{AA}}=-\frac{\partial \mathrm{P} / \partial \mathrm{P}_{\mathrm{N}}}{\partial \mathrm{P} / \partial \mathrm{P}_{\mathrm{T}}}=-\frac{\gamma_{\mathrm{N}} \mathrm{P} / \mathrm{P}_{\mathrm{N}}}{\gamma_{\mathrm{T}} \mathrm{P} / \mathrm{P}_{\mathrm{T}}}=-\frac{1-\gamma_{\mathrm{T}}}{\gamma_{\mathrm{T}}} \frac{\mathrm{P}_{\mathrm{T}}}{\mathrm{P}_{\mathrm{N}}},
$$

as $\gamma_{\mathrm{T}}+\gamma_{\mathrm{N}}=1$. As $\partial \mathrm{P} / \partial \mathrm{P}_{\mathrm{T}}>0$ and $\partial \mathrm{P} / \partial \mathrm{P}_{\mathrm{N}}>0$, the absolute price schedule is downward sloping. The absolute price schedule summarises the monetary side of the domestic economy. ${ }^{4}$

\footnotetext{
${ }^{4}$ While convexity of the absolute price schedule is a reasonable economic property (Clements and Semudram, 1983), Lan (2003) shows that for certain popular price indices, the absolute price schedules are not convex. Lan (2003) examines four explicit functional forms for the price level function, $P=P\left(P_{T}, P_{N}\right)$, (i) Laspeyres' index, (ii) the Paasche index, (iii) Fisher's ideal index, and (iv) the Cobb-Douglas index. In the cases of (i) and (ii), the absolute price schedules are both straight lines (with different slopes), which are special cases of a convex curve. When the price level is formulated as (iv), the absolute price schedule is convex to the origin. However, in the case of (iii), the absolute price schedule is concave. It is to be noted that what really matters for the absolute price schedule is not
} 
Note also that the homogeneity of the price level function means that the distance of the absolute price schedule from the origin is proportional to the price level. Suppose that along the absolute price schedule AA the price level is $\mathrm{P}_{0}$. A doubling of the money supply leads in the long run to a doubling of the price level to $2 \times \mathrm{P}_{0}$ and $\mathrm{AA}$ shifts up and to the right to $\mathrm{A}^{\prime} \mathrm{A}^{\prime}$. Then, the distance $\mathrm{OE}$ along the ray $\mathrm{OR}$ is proportional to $\mathrm{P}_{0}, \mathrm{OE}^{\prime}$ is proportional to $2 \times \mathrm{P}_{0}$ and $\mathrm{OE}^{\prime} / \mathrm{OE}=2$.

To relate the QTM to sectoral prices $\mathrm{P}_{\mathrm{T}}$ and $\mathrm{P}_{\mathrm{N}}$, consider the real side of the economy. Suppose that the equilibrium relative price of the traded goods in terms of nontrded goods is $\alpha$. Only when $\mathrm{P}_{\mathrm{T}} / \mathrm{P}_{\mathrm{N}}$ equals $\alpha$ are the excess demands for traded and nontraded goods zero, that is, the real economy is in equilibrium, so that the two nominal prices must lie somewhere along the ray from the origin OR in Figure 4. Accordingly, equilibrium in the real economy must lie somewhere on the ray OR that has slope $\alpha$. This ray is called the "relative price schedule". ${ }^{5}$ For the economy to simultaneously satisfy monetary equilibrium and for the relative price to be $\alpha$, the overall equilibrium must be located at the point $\mathrm{E}$ where the two curves intersect. A doubling of the money supply doubles the price level, moves the absolute price schedule from AA to $\mathrm{A}^{\prime} \mathrm{A}^{\prime}$, and with the relative price unchanged, the new equilibrium is at the point $\mathrm{E}^{\prime}$. The homogeneity of the price level function $\mathrm{P}=\mathrm{P}\left(\mathrm{P}_{\mathrm{T}}, \mathrm{P}_{\mathrm{N}}\right)$ means that the effect of doubling the quantity of money is to double both sectoral prices $\mathrm{P}_{\mathrm{T}}$ and $\mathrm{P}_{\mathrm{N}}$.

The above neutrality result can be established analytically as follows. The change in the price level is given by equation (1), which in view of $\gamma_{T}+\gamma_{N}=1$, can be written as $\hat{\mathrm{P}}=\gamma_{\mathrm{T}}\left(\hat{\mathrm{P}}_{\mathrm{T}}-\hat{\mathrm{P}}_{\mathrm{N}}\right)+\hat{\mathrm{P}}_{\mathrm{N}}=\hat{\mathrm{P}}_{\mathrm{N}}$ if $\mathrm{P}_{\mathrm{T}} / \mathrm{P}_{\mathrm{N}}$ is constant. But if $\mathrm{P}_{\mathrm{T}} / \mathrm{P}_{\mathrm{N}}=$ constant, $\hat{\mathrm{P}}_{\mathrm{T}}=\hat{\mathrm{P}}_{\mathrm{N}}$, so that $\hat{\mathrm{P}}_{\mathrm{N}}=\hat{\mathrm{P}}_{\mathrm{T}}=\hat{\mathrm{P}}$. The QTM then implies that this common increase in prices is equal to the growth in the money supply; that is, $\hat{\mathrm{P}}_{\mathrm{N}}=\hat{\mathrm{P}}_{\mathrm{T}}=\hat{\mathrm{P}}=\hat{\mathrm{M}}$. If, for example, the money stock doubles, $\hat{\mathrm{M}}=1$, so that $\hat{\mathrm{P}}=\hat{\mathrm{P}}_{\mathrm{N}}=\hat{\mathrm{P}}_{\mathrm{T}}=1$; in words, the two nominal sectoral prices also double.

Purchasing power parity (PPP) says that goods prices are equalised no matter where they are located. Let $\mathrm{P}_{\mathrm{T}}$ be the price of a market basket of traded goods at home, measured in terms of domestic currency, and $\mathrm{P}_{\mathrm{T}}^{*}$ be the corresponding price abroad, measured in terms of foreign currency. If $\mathrm{S}$ is the exchange rate, defined as the domestic currency cost of a unit of foreign

convexity, but the negative slope, which serves to keep the overall price level constant, as the combinations $\left(\mathrm{P}_{\mathrm{T}}, \mathrm{P}_{\mathrm{N}}\right)$ are varied.

${ }^{5}$ Note that it is only a matter of convenience that the ray OR is used for two purposes simultaneously: (i) The distance of the absolute price schedule from the origin along OR measures the price level; and (ii) OR is the relative price schedule. 
currency, the cost in terms of domestic currency of the foreign market basket is $\mathrm{SP}_{\mathrm{T}}^{*}$. PPP says that the cost of the two baskets is equalised when expressed in terms of domestic currency:

$$
\mathrm{P}_{\mathrm{T}}=\mathrm{SP}_{\mathrm{T}}^{*}
$$

or $\mathrm{S}=\mathrm{P}_{\mathrm{T}} / \mathrm{P}_{\mathrm{T}}^{*}$. In words, the exchange rate equals the price ratio, so that an increase in prices at home relative to those abroad, leads to an equi-proportional depreciation of the domestic currency:

$$
\hat{\mathrm{S}}=\hat{\mathrm{P}}_{\mathrm{T}}-\hat{\mathrm{P}}_{\mathrm{T}}^{*} \text {. }
$$

Equation (2) is known as absolute PPP, while (3) is relative PPP. Relative PPP is the weaker version as it is consistent with $\mathrm{P}_{\mathrm{T}}=\mathrm{KSP}_{\mathrm{T}}^{*}$, where $\mathrm{K}$ is a constant "wedge" between foreign and domestic prices that could be due to tariffs, other barriers to international trade, differences in national consumption patterns leading to different market baskets, etc. There is substantial controversy surrounding PPP theory involving concerns such as the nature of the parity, the mechanism that ensures it holds, whether it holds over the longer term in practice, the prices to which PPP refers, and so on. These issues are discussed extensively in the literature. ${ }^{6}$

Figure 5 illustrates the workings of PPP. The ray from the origin OS corresponds to equation (2) as it links prices of traded goods at home to those abroad via the exchange rate. Thus when domestic and foreign prices are $\mathrm{P}_{\mathrm{T} 0}$ and $\mathrm{P}_{\mathrm{T} 0}^{*}$, the PPP ray passes through this point and has slope $\mathrm{S}_{0}$. When domestic prices rise to $\mathrm{P}_{\mathrm{T} 1}$ and foreign prices remain unchanged, the ray becomes $\mathrm{OS}^{\prime}$. The slope of the ray increases from $\mathrm{S}_{0}$ to $\mathrm{S}_{1}$, which corresponds to a depreciation of the home country's currency. In summary, inflation at home leads to a weaker currency. Figure 6 uses two building blocks simultaneously:

- Monetary and real equilibrium, as set out in Figure 4, is reproduced in the right-hand panel of Figure 6.

- $\quad$ PPP is represented in the left-hand panel of Figure 6. The structure of this panel is the same as that of Figure 5, except now Figure 5 is "flipped over" so that an increase in foreign prices involves a move from right to left.

Figure 6 shows that as a result of an increase in the overall price level, the absolute price schedule shifts out from AA to $\mathrm{A}^{\prime} \mathrm{A}^{\prime}$, the equilibrium point moves from $\mathrm{E}$ (in the right hand panel), e (left panel), to $E^{\prime}, e^{\prime}$, and the domestic currency depreciates from $S_{0}$ to $S_{1}$.

\footnotetext{
${ }^{6}$ See, e.g., surveys by Froot and Rogoff (1995), Lan and Ong (2003), Rogoff (1996), Sarno and Taylor (2002), Taylor and Taylor (2004), and Taylor (2006). Possibly one of the most controversial issue is associated with the estimation of half-life of PPP deviations, which deals with the question, how long is the long run for PPP. Some of the issues discussed in this context include cross-sectional aggregation (see, e.g., Chen and Devereux, 2003, and Imbs et al., 2005), temporal aggregation (Chambers, 2004, Taylor, 2001), mis-specified models (Taylor, 2001), sampling error, incorrect approximations, and structural breaks in time series (Seong et al., 2006).
} 
Next, we wish to relate the money stock to the exchange rate directly by combining Figures 3 and 6. To do this, rotate Figure 3 clockwise so that the vertical axis coincides with the relative price schedule OR of Figure 6 and thereby obtain Figure 7. Figure 7 now reveals that an increase in the money stock leads to an equi-proportional depreciation of the currency.

What are the implications of the above monetary expansion for the real exchange rate, the price-level adjusted nominal rate? The real exchange rate is conventionally defined in terms of the natural logarithms as $\mathrm{q}=\log \left(\mathrm{P} / \mathrm{SP}^{*}\right)$. In Figure 7 , the increase in the price level leads to a proportional increase in the nominal exchange rate. As these two effects cancel each other out, the monetary expansion leaves the real exchange rate unchanged under the (natural) assumption that the foreign price level $\mathrm{P}^{*}$ remains unchanged. Here, monetary shocks have no transitory or permanent effects on the real exchange rate. It is to be noted that this conclusion is more plausible in the long run, when prices tend to be more flexible and fully adjust to changes in the money stock. $^{7}$ This neutrality of money result can be thought of as a benchmark case that can be used as a useful starting point for further analysis. In the next three sections, we consider situations in which the real exchange rate changes as a result of exogenous shocks.

\section{Exchange-Rate Overshooting}

In the above discussion, all prices are taken to be fully flexible in that they vary instantaneously with changes in the money stock. Accordingly, that analysis should be interpreted as referring to the long-run tendencies when frictions to price adjustment play little or no role, so that prices are likely to be more fully flexible. However, empirically sticky prices are important in the short run, especially with respect to labour-intensive services, the prices of which tend to be dominated by wages. The impact of sticky prices can be illustrated using the classification of traded and nontraded goods; the prices of traded goods tend to be more flexible as they typically relate more to commodities traded in organised markets, whereas the prices of nontraded goods are sticky in the short run due to contracts, menu costs, and other frictions.

Consider again the effects of an increase in the money supply. As before, immediately after this increase, the absolute price schedule moves outwards, from AA to $\mathrm{A}^{\prime} \mathrm{A}^{\prime}$ in the right-hand panel of Figure 8. Suppose that in the short run, the price of nontraded goods is fixed, which is the extreme case of sticky prices. This means that the price of traded goods has to "do all the adjusting” and this price must increase (in proportional terms) by more than the monetary expansion and the overall price level. This is illustrated in Figure 8 where the price of traded

\footnotetext{
${ }^{7}$ Recall from that Figure 1 that only in the long run do exchange rates and relative prices move closely together.
} 
goods increases from $\mathrm{P}_{\mathrm{T}}^{0}$ to $\mathrm{P}_{\mathrm{T}}^{1}$, while the price of nontraded goods remains unchanged at $\mathrm{P}_{\mathrm{N}}^{0}$. Accordingly, the relative price schedule moves anti-clockwise from $\mathrm{OR}$ to $\mathrm{OR}^{\prime}$, the relative price of traded goods rises from $\alpha_{0}$ to $\alpha_{1}$, and the overall equilibrium moves from the point $\mathrm{E}_{0}$ to $\mathrm{E}_{1}$. With the increase in the price of traded goods from $\mathrm{P}_{\mathrm{T}}^{0}$ to $\mathrm{P}_{\mathrm{T}}^{1}$, the nominal exchange rate thus increases instantaneously from $S_{0}$ to $S_{1}$, as shown in the left-hand panel of Figure 8 . Suppose that the original relative price $\alpha_{0}$ represents equilibrium in the goods market and the monetary expansion does nothing to disturb this in the long run. In such a case, the economy cannot remain at the equilibrium point $\mathrm{E}_{1}$, as here the relative price of traded goods is above the long-run equilibrium value $\alpha_{0}$. That is to say, at $E_{1}$ there is an excess supply for traded goods. Accordingly, over time this excess supply reduces the relative price of traded goods back down to its original level $\alpha_{0}$, and the equilibrium moves from $E_{0}$ to $E_{2}$, the intersection of the new absolute schedule $\mathrm{A}^{\prime} \mathrm{A}^{\prime}$, and the original relative price schedule, OR. The point $\mathrm{E}_{2}$ represents the new long-run equilibrium. The movement of the economy from $E_{1}$ to $E_{2}$ corresponds to the exchange rate appreciating from $S_{1}$ to $S_{2}$, as shown in the left-hand panel of Figure 8.

To summarise, the monetary expansion causes the exchange rate to initially depreciate from $S_{0}$ to $S_{1}$, but over time part of this initial depreciation is offset by a subsequent appreciation to $S_{2}$. The long-run effect of the monetary expansion is to depreciate the rate as $S_{2}>S_{0}$. Panel A of Figure 9 illustrates this time path. Due to sticky prices, the exchange rate initially depreciates by too much, so that it has to appreciate subsequently. This behaviour is consistent with the observed volatility of exchange rates and is known as "overshooting". This terminology was introduced by Dornbusch (1976) who explained it in a rational-expectations framework in which asset markets clear continuously, while goods prices are sticky. It should be clear that the above rendition of overshooting, which is due to Clements (1981), is a little different to Dornbusch's, but the result is the same.

How does the real exchange rate move in the case of nominal overshooting? We consider this question in three steps. First, nothing happens to the real exchange rate in the long run, as the move from $E_{0}$ to $E_{2}$ in Figure 8 simply involves a nominal depreciation equal to the increase in the price level. This is exactly the same as the situation in Figure 7. Therefore, the real exchange rate remains unchanged in the long run, so that if $\mathrm{q}_{0}$ and $\mathrm{q}_{2}$ are the initial and subsequent longrun values of the real exchange rate, then $\mathrm{q}_{2}=\mathrm{q}_{0}$, as shown in Panel B of Figure 9. Second, consider the instantaneous adjustment of the real exchange rate to the monetary expansion when the equilibrium point moves from $E_{0}$ to $E_{1}$ in Figure 8. As the nominal rate now depreciates by more than the increase in the price level, this involves a real depreciation, so that the new value of 
the real rate is $\mathrm{q}_{1}<\mathrm{q}_{0}$, as illustrated in Panel B of Figure 9. Third, all of this real depreciation is offset by the subsequent appreciation in the transition as the economy moves from the point $\mathrm{E}_{1}$ to the steady-state equilibrium point $\mathrm{E}_{2}$ in Figure 8, as represented by the movement back to the initial real rate $\mathrm{q}_{0}$ in Figure 9.

Overshooting can also be set out analytically as follows. As discussed above, the price level can be written in terms of proportional changes as

$$
\hat{\mathrm{P}}=\gamma \hat{\mathrm{P}}_{\mathrm{T}}+(1-\gamma) \hat{\mathrm{P}}_{\mathrm{N}},
$$

where the elasticity $0<\gamma<1$. Thus if $\hat{\mathrm{P}}_{\mathrm{N}}=0$ (that is, the extreme case of sticky prices of nontraded goods), then $\hat{\mathrm{P}}=\gamma \mathrm{P}_{\mathrm{T}}$, or

$$
\hat{\mathrm{P}}_{\mathrm{T}}=\frac{1}{\gamma} \hat{\mathrm{P}}>\hat{\mathrm{P}}
$$

so that the price of traded goods increases more than the price level. Application of purchasing power parity implies that the nominal rate moves proportionally with the price of traded goods, $\hat{\mathrm{S}}=\hat{\mathrm{P}}_{\mathrm{T}}$, or

$$
\hat{\mathrm{S}}=\frac{1}{\gamma} \hat{\mathrm{P}}=\frac{1}{\gamma} \hat{\mathrm{M}}
$$

where the second step is based on the quantity theory, $\hat{\mathrm{P}}=\hat{\mathrm{M}}$. This is the key overshooting result, whereby an increase in the money supply (and the overall price level) is magnified into the change in the exchange rate. The change in the real rate is then $\hat{\mathrm{q}}=\hat{\mathrm{P}}-\hat{\mathrm{S}}-\hat{\mathrm{P}}^{*}$, or

$$
\hat{\mathrm{q}}=\left(1-\frac{1}{\gamma}\right) \hat{\mathrm{P}}<0
$$

as $(1 / \gamma)>1$. In words, the real rate also depreciates in the short run.

The key evidence pointing to overshooting is that in the short run nominal exchange rates are more volatile than the corresponding price levels. ${ }^{8}$ Clements and Lan (2004) analyse overshooting in the context of this asymmetry in volatility as follows. Relative PPP implies that

$$
\Delta \mathrm{s}_{\mathrm{ct}}=\Delta \mathrm{r}_{\mathrm{ct}}
$$

where $\Delta \mathrm{s}_{\mathrm{ct}}=\log \mathrm{S}_{\mathrm{ct}}-\log \mathrm{S}_{\mathrm{c}, \mathrm{t}-1}$ is the change in the exchange rate and $\Delta \mathrm{r}_{\mathrm{ct}}=\log \left(\mathrm{P}_{\mathrm{ct}} / \mathrm{P}_{\mathrm{t}}^{*}\right)-\log \left(\mathrm{P}_{\mathrm{c}, \mathrm{t}-1} / \mathrm{P}_{\mathrm{t}-1}^{*}\right)$ is the inflation differential between the home country and abroad. Equation (4) implies that the variance of the exchange rate is equal to the variance of the inflation differential, which we express as $\operatorname{var}(\Delta s)=\operatorname{var}(\Delta r)$. Panel A of Figure 10, from

\footnotetext{
${ }^{8}$ But it should be acknowledged that in the literature there is still some controversy regarding the existence of overshooting. See Rogoff (2001) for a survey.
} 
Clements and Lan (2004), plots pairs of $\left(\Delta \mathrm{r}_{\mathrm{ct}}, \Delta \mathrm{s}_{\mathrm{ct}}\right)$ for 50 countries over the period of 19742004. Here the changes are annual and it can be seen that many of the points are of a considerable distance from the $45^{\circ}$ line, which corresponds to PPP. The root-mean-squared error (RMSE), a summary measure of the deviations from parity, is more than 12 percent, which is evidence against PPP holding over a one-year horizon. Note also that if we were to draw a "box" around the centre of gravity of the observations, the height of the box would be larger than its width. In this sense, exchange rates are more volatile than relative prices, which points to overshooting.

Next, consider the annual logarithmic change in the variable $X$ from year $t-2$ to $t-1$, $\Delta \mathrm{x}_{\mathrm{c}, \mathrm{t}-1}=\log \mathrm{X}_{\mathrm{c}, \mathrm{t}-1}-\log \mathrm{X}_{\mathrm{c}, \mathrm{t}-2}$, so that the PPP relationship becomes

$$
\Delta \mathrm{s}_{\mathrm{c}, \mathrm{t}-1}=\Delta \mathrm{r}_{\mathrm{c}, \mathrm{t}-1} .
$$

Adding both sides of equations (4) and (5) and then averaging yields

$$
\Delta \mathrm{s}_{\mathrm{ct}}^{(2)}=\Delta \mathrm{r}_{\mathrm{ct}}^{(2)} \text {, }
$$

where $\quad \Delta \mathrm{s}_{\mathrm{ct}}^{(2)}=\frac{1}{2}\left[\log \mathrm{S}_{\mathrm{ct}}-\log \mathrm{S}_{\mathrm{c}, \mathrm{t}-2}\right] \quad$ is the annualised log-change in $\mathrm{S}$ and $\Delta \mathrm{r}_{\mathrm{ct}}^{(2)}=\frac{1}{2}\left[\log \left(\mathrm{P}_{\mathrm{ct}} / \mathrm{P}_{\mathrm{c}, \mathrm{t}-2}\right)-\log \left(\mathrm{P}_{\mathrm{t}}^{*} / \mathrm{P}_{\mathrm{t}-2}^{*}\right)\right]$ is the corresponding annualised inflation differential, both with respect to a 2-year horizon. Equation (6) implies that $\operatorname{var}\left[\Delta s^{(2)}\right]=\operatorname{var}\left[\Delta r^{(2)}\right]$. A similar argument establishes that for any horizon m,

$$
\Delta \mathrm{s}_{\mathrm{ct}}^{(\mathrm{m})}=\Delta \mathrm{r}_{\mathrm{ct}}^{(\mathrm{m})}, \quad \text { and } \quad \operatorname{var}\left[\Delta \mathrm{s}^{(\mathrm{m})}\right]=\operatorname{var}\left[\Delta \mathrm{r}^{(\mathrm{m})}\right]
$$

where $\Delta \mathrm{x}_{\mathrm{t}}^{(\mathrm{m})}=\frac{1}{\mathrm{~m}}\left(\log \mathrm{X}_{\mathrm{t}}-\log \mathrm{X}_{\mathrm{t}-\mathrm{m}}\right)$. Panel B of Figure 10 contains a scatter plot for a horizon of $\mathrm{m}=30$ years. That is, this panel contains annualised 30-year changes, $\Delta \mathrm{s}_{\mathrm{ct}}^{(30)}$ and $\Delta \mathrm{r}_{\mathrm{ct}}^{(30)} \cdot{ }^{9}$ As the points are now much "closer" on average to the $45^{\circ}$ line, with the RMSE falling from about 12 to 2 percent, visually there seems to be impressive support for PPP in Panel B. Note also that the height of the box has now shrunken relative to its width, so that the box is now approximately square, implying that the volatility of exchange rates and prices are of the same order of magnitude. As we can interpret the 30-year changes as reflecting the long run, when all adjustments are complete, it can be seen why it is that many authors have emphasised that PPP only applies over the longer term, not on a year-to-year basis.

If we define the variance ratio as $\phi(m)=\operatorname{var}\left[\Delta s^{(m)}\right] / \operatorname{var}\left[\Delta r^{(m)}\right]$, equation (7) then implies $\phi(\mathrm{m})=1$ for any value of $\mathrm{m}$ under PPP. Figure 11, also from Clements and Lan (2004), plots the ratio of the variance of exchange rates to that of relative prices against the length of horizon. 
This illustrates that in comparison to relative prices, exchange rates in the short run are more volatile; for example, for a one-year horizon $m=1, \phi(1) \approx 3$, so that exchange rates are about three times as volatile as prices. But over the longer term, the volatility of the two variables seems to be of the same order of magnitude. This is also indicative of overshooting.

\section{The Productivity Bias}

Section 3 reviewed the relationship between exchange rates, money and prices. In establishing the neutrality of money in the long run, the theory allows no scope for interactions between the real and monetary sides of the economy. An important case in exchange-rate economics of the real economy affecting the nominal rate is what is known as the "productivity-bias" hypothesis of Balassa (1964) and Samuelson (1964). This section extends the theoretical framework of Section 3 and sets out the productivity-bias argument. ${ }^{10}$

Consider a three-country world, comprising a rich country, a poor one and the rest of the world. The term "productivity bias" refers to higher relative productivity in the production of traded goods in the rich country relative to that in the poor country. Relative to the poor country, the rich country can be more productive in producing both traded and nontraded goods, but its higher productivity is "amplified" in traded goods. This agrees with the idea that as nontraded goods tend to be labour-intensive, they are not as amenable as traded goods to productivity enhancements. Think of the high rates of productivity growth in mining and agriculture (that could be considered to the traded goods), as opposed to that in education (mostly a nontraded good). In this case, the price of traded goods in terms of nontraded goods is cheaper in the rich country in comparison to the poor country. If $\alpha$ is this relative price of traded goods (as before) and if $\mathrm{R}$ and $\mathrm{P}$ denote the rich and poor countries, then according to the productivity-bias hypothesis, $\alpha^{\mathrm{R}}<\alpha^{\mathrm{P}}$.

Figure 12 explores the implications of this difference in the structure of relative prices for the nominal exchange rate. To isolate the impact of the different structure of relative prices, we assume that the rich and poor countries both share the same absolute price schedule and face the same foreign prices. The left-hand panels of Figure 12, which apply PPP to traded goods, show that $S^{R}<S^{P}$, or that the currency of the rich country is worth more than that of the poor country, where both exchange rates are measured as the domestic currency cost of a unit of currency of the third country in the world. As both the rich and poor countries share the same absolute price

\footnotetext{
${ }^{9}$ Similar analyses are provided in Flood and Taylor (1996) and Isard (2004, p.49), Lothian (1985) and Obstfeld (1995).

${ }^{10}$ This section mainly draws on Clements and Lan (2006).
} 
schedule, they have the same price levels $\left(\mathrm{P}^{\mathrm{R}}=\mathrm{P}^{\mathrm{P}}\right)$; as they both face the same foreign price level $\mathrm{P}^{*}$ and as the rich country's exchange rate is lower $\left(\mathrm{S}^{\mathrm{R}}<\mathrm{S}^{\mathrm{P}}\right)$, it then follows that $\mathrm{q}^{\mathrm{R}}-\mathrm{q}^{\mathrm{P}}=\log \left(\mathrm{P}^{\mathrm{R}} / \mathrm{S}^{\mathrm{R}} \mathrm{P}^{*}\right)-\log \left(\mathrm{P}^{\mathrm{P}} / \mathrm{S}^{\mathrm{P}} \mathrm{P}^{*}\right)=\log \mathrm{S}^{\mathrm{P}}-\log \mathrm{S}^{\mathrm{R}}>0$. In words, in this case the difference in the real exchange rates is equal to the negative of its nominal counterpart, so that the nominal appreciation in moving from the poor to the rich country corresponds to an equiproportional appreciation of the real exchange rate. Therefore, countries where traded goods are relatively expensive tend to have cheap currencies in both nominal and real terms, and vice versa.

The implications of the above analysis are as follows:

(i) Application of PPP to price levels (whereby $\mathrm{S}=\mathrm{P} / \mathrm{P}^{*}$ ) indicates that the currencies of the two countries should have the same value.

(ii) PPP for traded goods only indicates that the currency of the rich country is worth more.

(iii) If currencies are in fact priced according to traded-goods PPP, whereas one values them according to price-level PPP, (i) and (ii) above jointly imply that the currency of the rich (poor) country is over (under) valued. This is the productivity-bias hypothesis.

Evidence on the extent of the productivity bias has been provided by a number of studies using the Penn World Table (PWT); see Samuelson (1994) and Summers and Heston (1991). Other recent empirical evidence include Bahmani-Oskooee and Gelan (2006), Clements and Lan (2007), DeLoach (2001), Ericsson and Irandoust (2004). Habermeier and Mesquita (1999), Heston et al. (1994) and Ito et al. (1997). Figure 13, reproduced from Clements and Lan (2007), plots two measures of GDP per capita in 1992 for 77 countries. The vertical axis gives country c's GDP in terms of US dollars, Y, calculated with the prevailing market exchange rate. Because of deviations due to the productivity bias, international comparisons of GDP based on market exchange rates usually give a misleading picture of international differences in real incomes and living standards. To overcome this problem, the International Comparison Program of the United Nations produces a consistent set of "PPP-based" GDP, available in the PWT. The horizontal axis of Figure 13 gives the PWT GDPs, $\tilde{Y}$. As can be seen, the low-income countries are all located below the $45^{\circ}$ line corresponding to $\mathrm{Y}=\tilde{\mathrm{Y}}$, while high-income counties are mostly above. This indicates that based on conventional GDP, poor countries' incomes tend to be underestimated, and rich countries' incomes tend to be overestimated. This is clear evidence in favor of the productivity-bias hypothesis. ${ }^{11}$

\footnotetext{
${ }^{11}$ However, it should also be acknowledged that there is some evidence against the Balassa-Samuelson theory (see, e.g., Bahmani-Oskooee and Niroomand, 1996, and Duval, 2001). One of the key assumptions in the BalassaSamuelson model, PPP in traded goods, is questioned in Canzoneri et al. (1999) and Engel (1999). Pricing to market (PTM), originally developed by Dornbusch (1987) and Krugman (1987), is offered as one explanation for the failure
} 


\section{6. $\quad$ A Booming Sector}

A recurring theme for mineral-exporting countries is the impact on the exchange rate of a commodity boom. A substantial increase in world prices, or a new discovery of a major ore body, raises concerns about the likely appreciation of the country's exchange rate, and the impact of that on the competitiveness of other industries in the traded goods sector. Such an appreciation would hurt producers of non-mining exports, as well as firms in the import-competing sectors. This is variously known as the "Gregory Thesis", the "Dutch disease”, "de-industrialisation”, and the "resources curse." Leading examples of this phenomenon include the discovery of gold in Australia in the 1850s, the gas boom in the Netherlands in the 1960s, North Sea Oil in the 1970s, and the experience in oil exporting countries of surges in oil prices. In a certain sense, the mechanism by which a boom in the minerals exporting sector hurts the country's other exporters and those in import-competing activities is a type of externality. Accordingly, a booming minerals sector can give rise to calls for government to use policy to internalise its effects, or to provide transition assistance to the sectors that will be hurt by the boom. It is thus important to understand the nature of this mechanism. In this section, we use an extension of the above framework to set out the economics of booming sectors. The next section reviews some other treatments of booming sectors and some empirical evidence.

To analyse the effects of an expansion of some export sector, we assume that the whole economy is divided into three broad sectors: Exportables, importables and nontraded goods, whose nominal prices are denoted by $\mathrm{P}_{\mathrm{E}}, \mathrm{P}_{\mathrm{M}}$ and $\mathrm{P}_{\mathrm{N}}$, respectively. Figure 14, from Dornbusch (1974), plots the relative price of importables in terms of nontraded goods, $\mathrm{p}_{\mathrm{M}} \equiv \mathrm{P}_{\mathrm{M}} / \mathrm{P}_{\mathrm{N}}$, against that of exportables, $\mathrm{p}_{\mathrm{E}} \equiv \mathrm{P}_{\mathrm{E}} / \mathrm{P}_{\mathrm{N}}$. Equilibrium in the market for nontraded goods requires that these two relative prices lie somewhere on the downward-sloping schedule labeled NN. To see this, take an arbitrary point on $\mathrm{NN}$ such as $\mathrm{X}$ and move in a due easterly direction to $\mathrm{Y}$. As this move entails a decrease in the price of nontraded goods relative to exportables, and as at $\mathrm{X}$ the market for nontraded goods initially cleared, at $\mathrm{Y}$ there is an excess demand for nontraded goods. This excess demand can be eliminated through increasing the relative price of nontraded goods in terms of importables by moving in a southerly direction from $\mathrm{Y}$ to $\mathrm{Z}$. At a point such as $\mathrm{Z}$, the market for nontraded goods clears again, which establishes that NN must be downward sloping. We assume that the country is small so that it faces given world prices of the two traded goods, $\mathrm{P}_{M}$ and $\mathrm{P}_{\mathrm{E}}$. The terms of trade are $\mathrm{P}_{\mathrm{M}} / \mathrm{P}_{\mathrm{E}} \equiv \mathrm{p}_{\mathrm{M}} / \mathrm{p}_{\mathrm{E}}$, which for a fixed value, $\left(\mathrm{p}_{\mathrm{M}} / \mathrm{p}_{\mathrm{E}}\right)_{0}$, is

of PPP with respect to traded goods. The low pass-through from exchange rates to prices and resultant failure of PPP for traded goods has been an important strand of the literature on exchange-rate economics. 
given by the slope of the ray from the origin in Figure 14 labelled OD. The clearing of both the markets for traded and nontraded goods occurs at the point $\mathrm{E}_{0}$, where OD and NN intersect.

In the previous paragraph, we established that points above the $\mathrm{NN}$ schedule represent excess demand for nontraded goods. But by Walras' Law, these points also represent excess supply of traded goods, which implies a surplus in the country's trade account. This also implies that those points lying below the $\mathrm{NN}$ schedule represent a trade-account deficit. Thus if the economy now experiences a boom in an export sector leading to an exogenous increase in those exports, points that previously constituted a trade-account deficit are now consistent with a zero trade balance, or equilibrium in the market for traded goods. All this means that the expansion of an export sector causes $\mathrm{NN}$ to move inward toward the origin, to $\mathrm{N}^{\prime} \mathrm{N}^{\prime}$. This causes the overall equilibrium to shift from $E_{0}$ to $E_{1}$, with the result that $\mathrm{p}_{\mathrm{M}}$ and $\mathrm{p}_{\mathrm{E}}$ both fall. Due to the decrease in the prices of importables and exportables that are not part of the expanding sector, the profitability of firms in these sectors is squeezed.

Next, to relate the prices of exportables and importables directly to the exchange rate, they need to be aggregated into "traded goods". If the shares of importables and exportables in traded goods are $\beta$ and $1-\beta$, respectively, we can define the price of traded goods (relative to nontraded goods) as a weighted average of its two components: $\mathrm{p}_{\mathrm{T}}=\beta \mathrm{p}_{\mathrm{M}}+(1-\beta) \mathrm{p}_{\mathrm{E}}$. Figure 15 gives a geometric presentation of this function and analyses how the price of traded goods changes as a result of a booming sector. Quadrant I of this figure reproduces Figure 14. Let us first look at the initial equilibrium point $E_{0}$ that corresponds to an importables price of $\mathrm{p}_{\mathrm{M}}^{0}$ and an exportables price of $\mathrm{p}_{\mathrm{E}}^{0}$. In Quadrant II, we draw a line from the origin OF which has a slope of $\beta$ with respect to the vertical axis. Then the distance $\mathrm{OA}_{0}$ on the left horizontal axis is $\beta$ times the initial price of importables $\mathrm{p}_{\mathrm{M}}^{0}$, i.e., it is the first component of the traded goods price, $\beta \mathrm{p}_{\mathrm{M}}^{0}$. Quadrant III simply transfers this importables component to the lower vertical axis Op$_{\mathrm{T}}$ through a $45^{\circ}$ line, so that the distance $\mathrm{OB}_{0}$ is of the same length as $\mathrm{OA}_{0}$. In quadrant IV, treating $\mathrm{B}_{0}$ as the origin, we add a line $\mathrm{B}_{0} \mathrm{G}$ which has a slope of $(1-\beta)$ with respect to the horizontal axis. Thus the distance $\mathrm{B}_{0} \mathrm{C}_{0}$ on the lower vertical axis $\mathrm{Op}_{\mathrm{T}}$ is $(1-\beta)$ times the exportable goods price $p_{E}^{0}$, i.e., it is the second component of the traded goods price $(1-\beta) \mathrm{p}_{\mathrm{E}}^{0}$. As $\mathrm{OC}_{0}=\mathrm{OB}_{0}+\mathrm{B}_{0} \mathrm{C}_{0}$, the distance $\mathrm{OC}_{0}$ is the weighted average of the importables and exportables prices; i.e., the distance $\mathrm{OC}_{0}$ represents the traded goods price $\mathrm{p}_{\mathrm{T}}^{0}$ corresponding to the initial equilibrium $E_{0}$. Recall that when there is a booming sector, the home goods schedule $\mathrm{NN}$ shifts down and towards the origin to $\mathrm{N}^{\prime} \mathrm{N}^{\prime}$, and the new equilibrium point is $\mathrm{E}_{1}$. Using the 
same geometric analysis, we obtain the distance $\mathrm{OC}_{1}$ on the lower vertical axis $\mathrm{Op}_{\mathrm{T}}$ as the traded goods price $\mathrm{p}_{\mathrm{T}}^{1}$ corresponding to the new equilibrium point $\mathrm{E}_{1}$. It can be seen from the figure that $\mathrm{p}_{\mathrm{T}}^{1}<\mathrm{p}_{\mathrm{T}}^{0}$, meaning that the price of traded goods (relative to nontraded goods) decreases as a result of a booming sector.

The above shows that the boom causes the relative price of traded goods at home to fall. This then implies that the domestic currency appreciates, which can be established as follows. Using the previous notation whereby the relative price $\mathrm{P}_{\mathrm{T}} / \mathrm{P}_{\mathrm{N}}$ was denoted by $\alpha$, we have $\hat{\mathrm{P}}_{\mathrm{T}}-\hat{\mathrm{P}}_{\mathrm{N}}=\hat{\alpha}$, or $\hat{\mathrm{P}}_{\mathrm{N}}=\hat{\mathrm{P}}_{\mathrm{T}}-\hat{\alpha}$. Substituting this expression in equation (1) gives

$$
\hat{\mathrm{P}}=\gamma_{\mathrm{T}} \hat{\mathrm{P}}_{\mathrm{T}}+\left(1-\gamma_{\mathrm{T}}\right)\left(\hat{\mathrm{P}}_{\mathrm{T}}-\hat{\alpha}\right),
$$

so that if the overall price level is held constant $(\hat{\mathrm{P}}=0)$,

$$
\hat{\mathrm{P}}_{\mathrm{T}}=\left(1-\gamma_{\mathrm{T}}\right) \hat{\alpha} \text {. }
$$

As the fall in the relative price of traded goods caused by the boom implies $\hat{\alpha}<0$, it follows that $\hat{\mathrm{P}}_{\mathrm{T}}<0$. Relative PPP then implies that $\hat{\mathrm{S}}=\hat{\mathrm{P}}_{\mathrm{T}}$ (when the foreign price of traded goods is held constant), so that the home country's exchange rate appreciates. As the expanding export sector has no effect on the overall price level, the nominal appreciation leads to an equi-proportional real appreciation, i.e., $\hat{\mathrm{q}}=-\hat{\mathrm{S}}>0$.

\section{7. $\quad$ More on Booming-Sector Effects}

Considerable research on the effect of a resource boom on a country's economy has emerged since the 1970s. Such an effect is known in the literature as the "Gregory effect", the "Dutch disease" and the "resource curse". This section reviews the perspectives provided by these three approaches, as well as some of the related empirical evidence.

\section{The Gregory Effect}

Australian economists figured prominently in the early empirical analysis of the booming sector effect, commencing with Gregory's (1976) influential study of the impact of a rapid growth of mineral exports on the sectoral structure of the Australian economy. Gregory's paper was the first attempt to understand the impact of the mining boom in Australia in the late 1960s on Australia's deteriorating macroeconomic performance (Dixon et al. 1982). Using a simple partial equilibrium model, Gregory showed that a minerals boom hurts the import-competing and the traditional exporting sectors and is comparable with the effect of a tariff increase on these sectors. These effects have become widely known in Australia as the Gregory effect. 
Snape (1977) extended Gregory's analysis by considering the effects of a minerals boom in a general equilibrium framework. He established that following a minerals boom:

- Tradeable production will increase;

- The price of nontraded goods will increase; and

- The production of nontraded goods could increase or decrease.

The first and second points are consistent with Gregory's result. However, the third point is not consistent with Gregory's suggestion that the size of sectors will change in the same direction as prices (Snape, 1977, pp. 151-153). While Gregory emphasised the potentially disruptive effect of movements in relative prices on those industries whose products are heavily traded, Snape identified that a minerals boom would also have income effects (Dixon et al., 1982, p. 351).

A further extension of Gregory’s work was provided by Stoeckel (1979). Both Gregory and Snape assumed that the mining sector expansion was due to the discovery of minerals, that is, an outward shift in the supply curve. Stoeckel expanded the analysis by considering both supply-side and demand-side changes as causes of a mining boom. Using a five-sector computable general equilibrium model, Stoeckel found that when the source of growth is a domestic supply shift, the import-competing manufacturing sector benefits from a minerals boom. This result is in direct contrast to Gregory's result. When the minerals boom is the result of an increase in demand for mineral exports, rather than new discoveries, the import-competing manufacturing sector contracts along with the agriculture sector. This is Gregory’s result (Choi, 1988, p. 108).

Further empirical analysis of the Australian mining boom was provided by Cook and Sieper (1984) also using a computable general equilibrium model. They considered the implications of a wide variety of assumptions about monetary policy, exchange rate and wage flexibility and intersectoral flexibility. They distinguished between the demand-side, or expenditure-augmenting, effects of the minerals sector expansion (the Gregory analysis) and the supply-side, or resourcemovement, effects that are the result of the minerals sector employing more factors of production.

Following Gregory's paper, the economics of resources booms and the Gregory effect became significant issues in Australian macroeconomic policy discussions (see, for example, Dornbusch and Fischer, 1984). Similarly, it received considerable attention in studies aimed at measuring the macroeconomic effects of major mining and energy projects using computable general equilibrium models; see, for example, Clements and Greig (1994), Dixon et al. (1979), Higgs and Powell (1992) and Ye (1999).

\section{The Dutch Disease}

The Gregory effect emerged in another guise in Britain and Europe in the early 1980s. The discovery of large natural gas deposits in the North Sea in the late 1950s led to an expansion of the 
Dutch natural gas sector. A consequent decline in the Dutch manufacturing sector as a result of the booming gas sector was labeled the Dutch disease by The Economist (1977). ${ }^{12}$ The adverse impacts on the manufacturing sector were widely attributed to the real appreciation of the exchange rate, that is, the Gregory effect. However, as Corden (1984, p. 359) pointed out, "it might be argued that the true Dutch disease in the Netherlands was not the adverse effects on manufacturing of real appreciation, but rather the use of booming sector revenues for social service levels, which are not sustainable, but which it has been politically difficult to reduce”. At about the same time, Britain also experienced the Dutch disease, with the booming sector being the North Sea oil and gas industry, which grew from close to zero to about 6 percent of GDP in around 10 years (Forsyth and Kay, 1980).

The first systematic analysis of Dutch disease was by Corden and Neary (1982). Their study drew on and extended the analysis of the Australian case by Gregory (1976) and Snape (1977). Corden and Neary's model is based on a small open economy made up of three sectors, a booming tradeable sector, a lagging or non-booming tradeable sector and a non-tradeable sector. The booming sector is typically the oil and gas sector, but can include other minerals. The lagging sector generally refers to manufacturing and/or agriculture. In their model a resources boom affects the economy in two ways. The first is a spending effect, which occurs as a result of additional expenditure on traded and nontraded goods arising from the higher domestic incomes as a result of the boom. The increased demand for nontraded goods leads to a rise in their relative price, that is, an appreciation of the real exchange rate, as the prices of traded goods are set internationally and remain unchanged. The higher relative price of the nontraded goods makes domestic production less attractive and so their output declines.

A second effect that emerges is the resource movement effect, which arises if the booming sector shares domestic factors of production with other sectors. The expansion of the booming sector tends to bid up the prices of these factors and causes them to shift from the lagging sector to the booming sector. In the case of labour, such a shift is called direct de-industrialisation. The resource movement effect reinforces the spending effect and the appreciation of the real exchange rate, producing the squeeze the on the lagging sector, creating the so-called Dutch disease. ${ }^{13}$

Corden (1984) extended the basic Corden-Neary model to take into account immigration, endogenous terms of trade effects, domestic absorption, unemployment, protectionist policies and dynamic issues. The treatment of these factors in models of Dutch disease may influence the

\footnotetext{
${ }^{12}$ Although the term Dutch disease is relatively new, the effects of minerals booms were noted over a century ago (Davis, 1995).

${ }^{13}$ This discussion on Dutch disease is based on Corden and Neary (1982), Corden (1984) and Neary and van Wijnbergen (1986).
} 
severity of the predicted effects of a boom on the manufacturing sector; and in fact, in some cases there may not be a Dutch disease at all (Bjornland, 1998).

A further development of the theory of the Dutch disease is provided in Neary and van Wijnbergen (1986). They examined the effect of a booming sector in a variety of theoretical models representative of those in the literature on Dutch disease, starting with the basic CordenNeary framework described above. In a paper in the same volume, Forsyth (1982) questioned the empirical evidence of Dutch disease in both Australia and Britain. He observed that while there is evidence of Dutch disease effects in both countries, it was impossible to measure the precise impact of the booms on structural change. In the Australian case, for the major minerals boom of 1968-74, the macroeconomy was in balance, but the mineral boom was small compared to the size of the sectors it was affecting (Forsyth, 1982, p. 282). Forsyth considered that there were more problems in interpreting the British case. While the broad pattern of changes was consistent with the Dutch disease, other factors had a significant influence. For example, North Sea oil was imposed on the British economy, which was performing poorly, and the boom itself probably affected this performance. That is, the structural effects of the Dutch disease were reinforced by using up the benefits of the boom over a short period.

In a more recent study, Bjornland (1998) analysed the economic effect of the oil and gas sector on manufacturing output of the United Kingdom and Norway. In contrast to many earlier studies, Bjornland used a vector autoregression (VAR) model to investigate whether there was evidence of Dutch disease arising from energy booms caused by the development of North Sea oil. She concluded that there was only weak evidence of the Dutch disease in the United Kingdom. In contrast, manufacturing output in Norway benefited from energy discoveries and higher oil prices. Krugman (1987) questioned whether the Dutch disease was in fact a problem at all. He pointed out that in conventional trade models, countries should specialise in whatever is their comparative advantage. In his view, a mineral boom simply shifts comparative advantage away from the manufacturing sector. Nevertheless, he acknowledged a concern that a contraction of a country's manufacturing sector following a boom may mean that the sector may not be able to recover after the boom.

\section{The Resource Curse}

Auty (1993) introduced the term "resource curse" to describe how countries rich in natural resources are not able to use that wealth to boost their economies, and consequently experienced lower economic growth than countries without an abundance of natural resources. Although "resource curse” and "Dutch disease” are terms that are frequently used interchangeably. as Davis (1995) pointed out, they are separate issues. The Dutch disease refers predominantly to the 
macroeconomic effects of an appreciation of the real exchange rate and changes in a country's productive structure resulting from an energy or minerals boom. It denotes the coexistence of booming and lagging sectors in an economy due to a temporary or sustained increase in export earnings. In other words, the Dutch disease is simply a description of the causes and structural effects of boom-induced growth.

In contrast, under the resource curse hypothesis, a mineral boom is interpreted as a net economic loss, where the present value of the positive effects of the boom is offset by the present value of the negative effects (Davis, 1995). The Dutch disease is one of a number of contributing factors to the negative effects of a boom. Other factors include excessive borrowing, corruption, government complacency and neglect of education. These factors have been identified in numerous studies that have shown a link between natural resource abundance and poor economic growth. Jeffery Sachs and Andrew Warner have figured prominently in this research; see, for example, Sachs and Warner (1995, 1997, 1999, 2001). ${ }^{14}$ Other important contributions include Auty (2001), Eggert (2001), Gelb (1988), and Gylfason et al. (1999).

A recently-published collection of papers (Lederman and Maloney, 2007a) suggests that there is still considerable uncertainty surrounding the relationship between resource abundance and economic growth. Lederman and Maloney (2007b) point to differences in defining "resource abundance" contributing to significant differences in the econometric evidence of the resource curse. Manzano and Rigobon (2007) suggest that the resource curse is not about resources per se, but relates more to imperfect credit markets. Bravo-Ortega and Gregario (2007) show that natural resources may lead to a decline in the rate of growth in countries with very low levels of human capital. Lederman and Maloney (2007b, p. 10) conclude that "in sum, this book provides ample statistical , historical, and theoretical evidence to suggest that natural resources are neither a curse nor destiny for developing countries”.

\section{Exchange Rate Forecasting}

Given that most resources companies now tend to shun hedging, being able to forecast exchange rates accurately has become one of their crucial tasks. This section first discusses the most frequently used approach to exchange rate forecasting -- structural exchange-rate models based on fundamentals, as well as linear and non-linear time series models. It then briefly touches upon other two approaches, surveys and composite forecasts, before it turns to recent research on PPPbased exchange rate forecasting.

\footnotetext{
14 Stijns (2005) provides a comprehensive review of the main Dutch disease models that have been designed to generate a form of resource curse in response to a resources boom.
} 
It is widely known that it is notoriously difficult to forecast exchange rates given their volatility. As Faust et al. (2003) put it, "even after the fact, analysts are hard-pressed to explain movements in exchange rates through reference to macroeconomic fundamentals.” The popularity of macroeconomic fundamentals in explaining exchange rates is due to the rational expectations efficient market model developed in the 1970s, which has been the dominant theory of exchange rates and includes the monetary model, the Dornbusch model and the portfolio balance model. This model states that exchange rate changes can only be induced by unexpected changes (news) in the underlying fundamentals such as inflation, output growth, interest rates, etc. However, this class of models does not pass empirical scrutiny as the influential paper by Meese and Rogoff (1983) demonstrates that they cannot outperform the random walk model in predicating exchange rates. The failure of fundamentals models may be one explanation of the excess volatility of exchange rates mentioned in Section 1, and the frequent disconnection of exchange rates from their underlying fundamentals. ${ }^{15}$ But at the same time, there is a strand of the literature that find that fundamentals models are useful in predicating exchange rates at long-horizons (e.g, Mark 1995). There now even seems to be an emerging consensus that theoretical exchange rate models are "not as bad as you think"; see Engel (2006) for a discussion.

Besides the fundamentals approach, other model-based approaches to forecasting exchange rates include linear and non-linear time-series models, which disregard fundamentals and model purely the evolution of random variables. Examples of linear time series models are the random walk, ARIMA, or multivariate systems models such as the VAR model and the VECM. Popular nonlinear models include neural networks, the simultaneous nearest-neighbour approach, etc. There is also an important strand of research that takes weighted averages of forecasts from alternative models; see, e.g., MacDonald and Marsh (1994), and Qi and Wu (2003). In addition, survey forecasts of exchange rates from business economists are frequently reported in the media, some of which are based on the above-mentioned model-based approaches, while others are probably purely professional guess. Interestingly, Mitchell and Pearce (2006) find that no economist can consistently outperform the survey average.

In the last decade or so, there has been a noticeable resurgence of interest in PPP as a theory of exchange rate determination in the long run. PPP-based exchange-rate forecasts belong to the fundamentals stream of the model-based approach, and use the price levels in two countries in questions as fundamentals. Section 3 mentioned two version of PPP, the absolute version, and the

\footnotetext{
${ }^{15}$ Whether the consideration of non-linearity in fundamentals models improves forecast performance is subject to debate. Several recent papers, Obstfeld and Taylor (1997), Michael et al. (1997), Killian and Taylor (2003), among others, shows that when further away from the fundamentals, exchange rates have faster adjustment speed toward their equilibrium values. However, other research (e.g., Engel, 1994, Meese and Rose, 1991) shows that non-linear adjustment does not produce forecast gains.
} 
relative version, where the changes in the exchange rates and in the relative price are exact. In practice, this is too rigid and a third version, stochastic PPP, is used to model the relationship between exchange-rate and prices. Instead of treating the real exchange rate as a constant, i.e., $\quad \mathrm{q}=\log \left[\mathrm{P} /\left(\mathrm{SP}^{*}\right)\right]=\mathrm{k}$, the stochastic version allows for random deviations and estimates the constant by modelling time-series properties of the real exchange rate, i.e., $\mathrm{q}=\log \left[\mathrm{P} /\left(\mathrm{SP}^{*}\right)\right]=\mathrm{k}+\varepsilon$, where $\varepsilon$ is the random term with zero mean. This constant $\mathrm{k}$ is the equilibrium exchange rate and the centre of gravity to which the real exchange rate reverts in the long run. In an instructive metaphor, The Economist magazine (of $26^{\text {th }}$ August 1995) describes such deviations in the following terms:

"Suppose a man climbs five feet up a sea wall, then climbs down twelve feet. Whether he drowns or not depends upon how high above sea-level he was when he started. The same problem arises in deciding whether currencies are under- or over-valued.”

The value of the exchange rate is analogous to the position of the man on the sea wall and the equilibrium rate is the sea-level, so that whether the currency is correctly priced by the market is determined by reference to its equilibrium value. ${ }^{16}$ The identification of the equilibrium value of a currency with sea-level accords with the idea that "water finds its own level”. That is, over time, the actual value of the currency should tend to revert to its equilibrium value. This is confirmed by the long-run tendency of the three currencies in Figure 1 to revert to the price ratio. This suggests that PPP has some informational content in this instance as an indicator of future exchange-rate movements.

Whether or not a currency is at its right level is an issue of major controversy. This issue has major implications for economic policy, the smooth functioning of financial markets, and the financial management of resources companies. For these reasons, in 1986 The Economist magazine invented the Big Mac Index (BMI), which gives a “quick and easy” method of valuing currencies. Over the 20 years' of its existence, the BMI has stimulated an important strand of academic literature in PPP called Burgernomics (see, e.g., Cumby, 1996, Lan, 2006, Ong, 1997, 2003, Pakko and Pollard, 1996, 2003). It has also played an important role in popularising PPP and bringing its practical implications to the attention of financial markets.

\footnotetext{
${ }^{16}$ One further point should be made about the metaphor from The Economist. As real factors change, it is natural to expect the country's real exchange rate to also adjust. For example, a major real depreciation of the currency may be required to correct an imbalance in the country's balance of payments. Despite its brilliance, the metaphor is thus a little overdramatic in implying that if the value of a country's currency falls below parity, this is a fate akin to death (i.e., the man drowns). Such an attitude to the value of the country's currency would reflect mercantilist sentiments. However, it is said that The Economist employs a style of writing that involves "simplification and then exaggeration." The metaphor may of course just be a manifestation of this exaggeration, rather than reflecting mercantilist elements at The Economist.
} 
Employing the PPP approach to exchange-rate forecasting, Xu (2003) uses differing broad price indices to define real exchange rates and finds that PPP does generate superior exchange rate forecasts. Clements and Lan (2006) propose a new approach to forecasting exchange rates using the Big Mac data. They argue that using broad price indices such as the CPI are subject to serious problems such as infrequent availability, sampling errors, differences in consumption patterns in different countries, etc. Their exchange-rate forecasts are based on real-time data of exchange rates and Big Mac prices and are obtained through Monte Carlo simulation, which gives rise to the entire distribution of the forecasts, not just a single point estimate. The provision of such forecast uncertainty enables market participants to make financial decisions in an informed manner with the appropriate degree of caution. Clements and Lan also show that their approach beats the random walk model over the medium to longer term, even though the random walk model still dominates for very short horizons.

\section{Concluding Comments}

This paper analysed key aspects of exchange-rate economics for the resources sector. We started with a discussion of the importance of currency volatility and risk management, and to focus the discussion on the determinants of exchange rates, we then used a stylised model that emphasises the quantity theory of money and purchasing power parity. The paper applied this model to examine the behavior of exchange rates resulting from three kinds of shocks:

(i) A monetary expansion with flexible prices or sticky prices;

(ii) the increase in productivity of the traded-goods sector; and

(iii) a booming export sector.

Table 1 summarises their influences on the nominal exchange rates and its real counterpart (the price-level-adjusted nominal rate).

Exchange-rate economics is a controversial area with many claims, counterclaims and differing approaches that yield seemingly conflicting results. We unapologetically use a framework that has at its heart the quantity theory of money and purchasing power parity. This approach is attractive in its simplicity, its use of appealing economic principles and its clean predictions. However, our approach has more than just aesthetic appeal as it matches at least some well-established empirical regularities in the behaviour of exchange rates such as their volatility over the short term, the impact of differential productivity levels and currency appreciation brought about by a resources boom. 


\section{References}

Auty, R. M. (1993). Sustaining Development in Mineral Economies: The Resource Curse Thesis. London: Routledge.

Auty, R. M. (2001). “The Political Economy of Resource-Driven Growth.” European Economic Review 45: 839-46.

Bahmani-Oskooee, M. and A. Gelan (2006)."Black Market Exchange Rate and the Productivity Bias Hypothesis.” Economics Letters 91: 243-249.

Bahmani-Oskooee, M. and F. Niroomand (1996). "A Reexamination of Balassa's Productivity Bias Hypothesis.” Economic Development and Cultural Change 45: 195-204.

Balassa, B. (1964). "The Purchasing-Power Parity Doctrine: A Reappraisal.” Journal of Political Economy 72: 584-96.

Becker, C. and D. Fabbro (2006). "Limiting Foreign Exchange Exposure through Hedging: The Australian Experience.” Research Bank of Australia Discussion Paper, RDP2006-09.

Bjornland, H. C. (1998). "The Economic Effects of North Sea Oil on the Manufacturing Sector." Scottish Journal of Political Economy 45: 553-85.

Bravo-Ortega, C., and J. de Gregorio (2007). "The Relative Richness of the Poor? Natural Resources, Human Capital, and Economic Growth.” Chapter 4 in Lederman and Maloney (eds) Natural Resources: Neither Curse nor Destiny. Washington, DC: World Bank and Stanford University Press. Pp. 71-100.

Canzoneri, M. B., R. E. Cumby and B. Diba (1999). "Relative Labor Productivity and the Real Exchange Rate in the Long Run: Evidence for a Panel of OECD Countries.” Journal of International Economics 47: 245-66.

Chambers M. J. (2004). “The Purchasing Power Parity Puzzle, Temporal Aggregation, and HalfLife Estimation.” Economics Letters 86: 193-198.

Chand, S., and T. Levantis (2000). "Dutch Disease and the Crime Epidemic: An Investigation of the Mineral Boom in Papua New Guinea.” Australian Journal of Agricultural and Resource Economics 44: 129-146.

Chen L. L. and J. Devereux (2003). "What can US City Price Data Tell Us About Purchasing Power Parity?” Journal of International Money and Finance 22: 213-222.

Choi, K. H. (1988). Essays in Economic Aspects of Protection. Master of Economics Thesis, Economic Research Centre, Department of Economics, The University of Western Australia. Pp. i-viii, 1-157.

Clements, K. W. (1981). “The Monetary Approach to Exchange Rate Determination: A Geometric Analysis.” Weltwirtschaftliches Archiv 117: 20-29.

Clements, K. W. and R. Fry (2006). "Commodity Currencies and Currency Commodities." Discussion Paper 06.17, Economics Program, UWA Business School, The University of Western Australia.

Clements, K. W. and R. A. Greig (1994). Modelling Large-Scale Resource Development Projects in an Open Economy: The Case of Australia's North West Shelf Project. Mt Pleasant, Michigan: Blackstone.

Clements, K. W. and Y. Lan (2004). "How Long is the Long Run? Evidence from the Foreign Exchange Market." In H. Pan, D. Sornette and K. Kortanek (eds) Intelligent Finance: A Convergence of Mathematical Finance with Technical and Fundamental Analysis. Proceedings of The First International Workshop on Intelligent Finance (IWIF1), 13-14 December, Melbourne, Australia. Pp. 74-88.

Clements, K. W. and Y. Lan (2006). “A New Approach to Forecasting Exchange Rates." Discussion Paper 06.29, Economic Program, UWA Business School, The University of Western Australia.

Clements, K. W. and Y. Lan (2007). "Exchange Rates, Productivity, Poverty and Inequality.” Applied Economics 39: 471 - 476. 
Clements, K. W. and M. Semudram (1983). "An International Comparison of the Price of Nontraded Goods.” Weltwirtschaftliches Archiv 119: 356-63.

Cook, L. H. and E. Sieper (1984). "Minerals Sector Growth and Structural Change." Chapter 3 in L. H. Cook and M. G. Porter (eds) The Minerals Sector and the Australian Economy. Sydney: George Allen and Unwin. Pp. 85-127.

Corden, W. M. (1981). "The Exchange Rate, Monetary Policy and North Sea Oil: The Economic Theory of the Squeeze On Tradeables.” Oxford Economic Papers 33: 23-46.

Corden, W. M. (1982). "Exchange Rate Policy and the Resources Boom.” The Economic Record 58: $18-31$.

Corden, W. M. (1984). "Booming Sector and Dutch Disease Economics: Survey and Consolidation.” Oxford Economic Papers 36: 359-80.

Corden, W. M. and J. P. Neary (1982). "Booming Sector and De-Industrialisation in a Small Open Economy.” Economic Journal 92: 825-48.

Corden, W. M., and P. J. Neary (1982). "Booming Sector and De-Industrialisation in a Small Open Economy.” Economic Journal 92: 825-48.

Cross, J. (2003). "From Giant Maples to Bonsai The Decline of Producer Hedging." Paper Presented to the London Bullion Market Association Annual Conference, Lisbon, June 2003.

Cumby, R. E. (1996). "Forecasting Exchange Rates and Relative Prices with the Hamburger Standard: Is What You Want What You Get with McParity?” NBER Research Paper 5675.

Davis, G. M. (1995). "Learning to Love the Dutch Disease: Evidence from the Mineral Economies.” World Development 23: 1765-79.

DeLoach, S. B. (2001). "More Evidence in Favour of the Balassa-Samuelson Hypothesis." Review of International Economics 9:336-342.

Dixon, P. B., B. R. Parmenter, J. Sutton and D. P. Vincent (1982). ORANI: A Multisectoral Model of the Australian Economy. Amsterdam/New York/Oxford: North-Holland Publishing Company.

Dixon, P. B., A. A. Powell and B. R. Parmenter (1979). Structural Adaptation in an Ailing Macroeconomy. Melbourne: Melbourne University Press.

Dornbusch, R. (1974). “Tariffs and Nontraded Goods.” Journal of International Economics 4: 177-85. Reprinted as Chapter 15 in R. Dornbusch (1988) Exchange Rates and Inflation. Massachusetts and London: MIT Press.

Dornbusch, R. (1976). "Expectations and Exchange Rate Dynamics.” Journal of Political Economy 84: 1161-76. Reprinted as Chapter 4 in R. Dornbusch (1988) $\underline{\text { Exchange Rates and }}$ Inflation. Massachusetts and London: MIT Press.

Dornbusch, R. and S. Fischer (1984). "The Australian Macroeconomy.” In Caves, R. E. and L. B. Krause (eds) The Australian Economy: A View from the North. Sydney: Allen and Unwin. Pp. 25-79.

Dornbusch, R. (1987). “Exchange Rates and Prices.” American Economic Review 77: 93-106.

Duval, R. (2001). “The Real Exchange Rate and the 'Balassa-Samuelson' Effect.” Economie Internationale 85: 101-28.

Eggert, R. G. (2001). "Mining and Economic Sustainability: National Economies and Local Communities.” A Study Prepared for the Mining, Minerals, and Sustainable Development Project, Colorado School of Mines.

Engel, C. (1994). “Can the Markov Switching Model Forecast Exchange Rates?” Journal of International Economics 36: 151- 165.

Engel, C. (1999). “Accounting for U.S. Real Exchange Rate Changes.” Journal of Political Economy 107: 507-38.

Engel, C. (2006). “Exchange-Rate Models.” NBER Reporter, Fall 2006.

Ericsson, J. and M. Irandoust (2004). "The Productivity Bias Hypothesis and the PPP Theorem: New Evidence from Panel Vector Autoregressive Models.” Japan and the World Economy 16: 121-138. 
Faust, J., J. Rogers and J. Wright (2003). “Exchange Rate Forecasting: The Errors We’ve Really Made.” Journal of International Economics 60: 35-60.

Fisher, I. (1922). The Making of Index Numbers. Boston: Houghton Muffin.

Flood, R. and M. Taylor (1996). "Exchange Rate Economics: What's Wrong with the Conventional Macro Approach?” In J. Frankel, G. Galli and A. Giocannini (eds) The Microstructure of Foreign Exchange Markets. Chicago: The University of Chicago Press. Pp. 261-294.

Forsyth, P. J. (1982). "The Australian Mining Boom and British North Sea Oil: A Comparison of Their Economic Effects.” Working Paper 8252B, Centre for Studies in Money, Banking and Finance, Macquarie University.

Forsyth, P. J., and J. A. Kay (1980). "The Economic Implications of North Sea Oil Revenues.” Fiscal Studies 1: 1-28.

Frankel, J. A. and A. K. Rose (1995). "Empirical Research on Nominal Exchange Rates.” In G. Grossman and K. Rogoff (eds) Handbook of International Economics, Volume 3. Amsterdam: North Holland. Pp. 1689-1729.

Friedman, M. (1956). “The Quantity Theory of Money - A Restatement.” Chapter 1 in M. Friedman (ed) Studies in the Quantity Theory of Money. Chicago: The University of Chicago Press. Pp. 3-21.

Froot, K. A. and K. Rogoff (1995). "Perspectives on PPP and Long-Run Real Exchange Rates.” In G. Grossman and K. Rogoff (eds) Handbook of International Economics. Volume 3. Amsterdam: North-Holland. Pp. 1647-1688.

Gelb, A. H (1988). Windfall Gains: Blessing or Curse? New York: Oxford University Press.

Gregory, R. G. (1976). "Some Implications of the Growth of the Mineral Sector.” The Australian Journal of Agricultural Economics 20: 71-91.

Gylfason, T., T. T. Herbertsson and G. Zoega (1999). “A Mixed Blessing: Natural Resources and Economic Growth.” Macroeconomic Dynamics 3: 204-25.

Habermeier, K. F. and M. Mesquita (1999). "Long-Run Exchange Rate Dynamics: A Real Data Study.” IMF Working Paper 99/50. Washington DC: International Monetary Fund.

Heston, A., D. A. Nuxoll and R. Summers (1994). "The Differential-Productivity Hypothesis and Purchasing-Power Parities: Some New Evidence.” Review of International Economics 2: 22743.

Higgs, P. J. and A. A. Powell (1992). “Australia's North-West Shelf Gas Project: A General Equilibrium Analysis of its Impact on the Australian Economy.” Resources Policy 18: 179190.

Imbs, J., H. Mumtaz, M. O. Ravn and H. Rey (2005). "PPP Strikes Back: Aggregation and the Real Exchange Rate.” Quarterly Journal of Economics 120: 1-44.

Isard, P. (1995). Exchange Rate Economics. Cambridge: Cambridge University Press.

Isard, P. (2004). Globalization and the International Financial System: What's Wrong and What Can be Done? Massachusetts: Cambridge University Press.

Ito, T., P. Isard and S. Symansky (1997). "Economic Growth and Real Exchange Rate: An Overview of the Balassa-Samuelson Hypothesis in Asia.” NBER Working Paper 5979.

Johnson, H. G. (1971). “The Keynesian Revolution and the Monetarist Counter-Revolution.” American Economic Review 2: 91-106.

Killian, L. and M. Taylor (2003). "Why is it So Difficult to Beat the Random Walk Forecast of Exchange Rates?” Journal of International Economics 60: 85-107.

Krugman, P. (1987). "The Narrow Moving Band, The Dutch Disease, and Competitive Consequences of Mrs Thatcher: Notes on Trade in the Presence of Dynamic Scale Economies.” Journal of Development Economics 27: 41-55.

Krugman, P. (1993). "Recent Thinking About Exchange Rate Determination and Policy." In A. Blundell-Wignall (ed) The Exchange Rate, International Trade and The Balance of Payments. Sydney: Reserve Bank of Australia. Pp. 6-21. 
Lan, Y. (2003). “The Long-Term Behaviour of Exchange Rates.” PhD Thesis, Economic Program, UWA Business School, The University of Western Australia.

Lan, Y. (2006). "Equilibrium Exchange Rates and Currency Forecasts: A Big Mac Perspective.” International Economics and Finance Journal 1: 291-311.

Lan Y. and L. L. Ong (2003). "The Growing Evidence on Purchasing Power Parity." In L. L. Ong The Big Mac Index: Applications of Purchasing Power Parity. UK: Palgrave MacMillan. Pp. 29-50.

Lederman, D., and W. F. Maloney (2007a). Natural Resources: Neither Curse Nor Destiny. Washington, DC: World Bank and Stanford University Press.

Lederman, D. and W. F. Maloney (2007b). "Neither Curse Nor Destiny: Introduction to Natural Resources and Development.” Chapter 1 in Lederman and Maloney (2007a).

Lothian, J. R. (1985). "Equilibrium Relationships between Money and Other Economic Variables.” American Economic Review 75: 828-35.

MacDonald, R. and I. W. Marsh (1994). "Combining Exchange Rate Forecasts: What is the Optimal Consensus Measure?” Journal of Forecasting 13: 313-332.

Maloney, P. J. (1990). “Managing Currency Exposure: The Case of Western Mining.” Journal of Applied Corporate Finance 2: 1078-1196.

Manzano, O., and R. Rigobon (2007). "Resource Curse or Debt Overhang." Chapter 3 in Lederman and Maloney (eds) Natural Resources: Neither Curse nor Destiny. Washington, DC: World Bank and Stanford University Press. Pp. 41-70.

Mark, N. C. (1995). "Exchange Rates and Fundamentals: Evidence on Long-Horizon Predictability and Overshooting.” American Economic Review 85: 201-218.

Meese, R. and K. Rogoff (1983). "Empirical Exchange Rate Models of the Seventies: Do They Fit Out of Sample?” Journal of International Economics 14: 3-24.

Meese, R. A. and A. K. Rose (1991). "An Empirical Assessment of Non-Linearities in Models of Exchange Rate Determination.” Review of Economic Studies 58: 603-619.

Michael, P., A. R. Nobay and D. A. Peel (1997). "Transaction Costs and Nonlinear Adjustment in Real Exchange Rates: An Empirical Investigation.” Journal of Political Economy 105: 862879.

Mitchell, K. and D. K. Pearce (2006). "Can Business Economists Predict Interest Rate or Exchange Rate Movements?” Corporate Finance Review 10: 15-27.

Mitsui Global Precious Metals, Virtual Metals and Haliburton Mineral Services (2006). "Q3 2006 The Hedge Book.” Available at http://www.virtualmetals.co.uk/pdf/Q3\%2006\%20The\%20 Hedge\%20Book.pdf.

Neary J. P. and S. van Wijnbergen (1986). Natural Resources and the Macroeconomy. Oxford: Basil and Blackwell.

Obstfeld, M. (1995). “International Currency Experience: New Lessons and Lessons Relearned.” Brookings Papers on Economic Activity 1: 119-220.

Obstfeld, M. and K. Rogoff (1995). “Exchange Rate Dynamics Redux.” Journal of Political Economy 103: 624-60.

Obstfeld, M. and A. M. Taylor (1997). "Nonlinear Aspects of Goods-Market Arbitrage and Adjustment: Heckscher's Commodity Points Revisited.” Journal of the Japanese and International Economies 11: 441-479.

Ong, L. L. (1997). "Burgernomics: the Economics of the Big Mac Standard." Journal of International Money and Finance 16: 865-878.

Ong, L. L. (2003). The Big Mac Index: Applications of Purchasing Power Parity. UK: Palgrave Macmillan.

Pakko, M. R. and Pollard, P. S. (1996). "For Here or To Go? Purchasing Power Parity and the Big Mac.” Federal Reserve Bank of St. Louis Review 78: 3-21.

Pakko, M. R. and Pollard, P. S. (2003). "Burgernomics: A Big Mac ${ }^{\mathrm{TM}}$ Guide to Purchasing Power Parity.” Federal Reserve Bank of St. Louis Review 85(6): 9-27. 
Patinkin, D. (1969). “The Chicago Tradition, the Quantity Theory, and Friedman.” Journal of Money, Credit and Banking 1: 46-70.

Qi, M. and Y. Wu (2003). "Nonlinear Prediction of Exchange Rates with Monetary Fundamentals.” Journal of Empirical Finance 10: 623-40.

Rogoff, K. (1996). “The Purchasing Power Parity Puzzle.” Journal of Economic Literature 34: 647-668.

Rogoff, K. (2001). “Dornbusch’s Overshooting Model after Twenty-Five Years.” IMF Second Annual Research Conference on the Mundell-Fleming Lecture. Also Published as IMF Working Papers 02/39. Washington DC: International Monetary Fund.

Sachs, J. D., and A. M. Warner (1995). "Natural Resource Abundance and Economic Growth.” NBER Working Paper No. W5398.

Sachs, J. D., and A. M. Warner (1997). “Sources of Slow Growth in African Economies.” Journal of African Economies 6: 335-76.

Sachs, J. D., and A. M. Warner (1999). “The Big Push, Natural Resource Booms and Growth.” Journal of Development Economics 59: 43-76.

Sachs, J. D., and A. M. Warner (2001). “The Curse of Natural Resources.” European Economic Review 45: 827-38.

Samuelson, P. A. (1964). "Theoretical Notes on Trade Problems.” Review of Economics and Statistics 46: 145-54.

Samuelson, P. A. (1994). "Facets of Balassa-Samuelson Thirty Years Later.” $\underline{\text { Review of }}$ International Economics 2: 201-26.

Sarno, L. and M.P. Taylor (2002). The Economics of Exchange Rates. Cambridge: Cambridge University Press.

Seong, B, A. K. M. Mahbub Morshed and S. K. Ahn (2006). “Additional Sources of Bias in Halflife Estimation.” Computational Statistics \& Data Analysis 51: 2056-2064.

Snape, R. H. (1977). "Effects of Mineral Development on the Economy.” The Australian Journal of Agricultural Economics 21: 147-156.

Stijns, J-P. C. (2005). “Natural Resource Abundance and Economic Growth Revisited.” Resources Policy 30: 107-130.

Stoeckel, A. (1979). "Some General Equilibrium Effects of Mining Growth on the Economy." Australian Journal of Agricultural Economics 23: 1-22.

Summers, R. and A. Heston (1991). "The Penn World Table (Mark 5): An Expanded Set of International Comparisons, 1950-1988.” Quarterly Journal of Economics 106: 327-68.

Taylor, A. M. (2001). "Potential Pitfalls for the Purchasing-Power-Parity Puzzle? Sampling and Specification Biases in Mean-Reversion Tests of the Law of One Price.” Econometrica 69: 473-498.

Taylor, A. M. and M. P. Taylor (2004). “The Purchasing Power Parity Debate.” Journal of Economic Perspectives 18: 135-58.

Taylor, M. P. (1995). “The Economics of Exchange Rates.” Journal of Economic Literature 33: 1347.

Taylor, M. P. (2006). "Real Exchange Rates and Purchasing Power Parity: Mean Reversion in Economic Thought.” Applied Financial Economics 16: 1-17.

Tufano, P. (1996). "Who Manages Risk? An Empirical Examination of Risk Management Practices in the Gold Mining Industry.” Journal of Finance 51: 1097-1137.

Usui, N. (1997). "Dutch Disease and Policy Adjustment to the Oil Boom: A Comparative Study of Indonesia and Mexico.” Resources Policy 23: 151-62.

Warr, P. (2006). “The Gregory Thesis Visits the Tropics.” The Economic Record 82: 177-194.

Xu, Z. (2003). "Purchasing Power Parity, Price Indices, and Exchange Rate Forecasts.” Journal of International Money and Finance 22: 105-130.

Ye, Q. (1999). "How Different is Mining from Mineral Processing? A General Equilibrium Analysis of New Resource Projects in Western Australia.” Australian Journal of Agricultural and Resource Economics 43: 279-304. 
FIGURE 1

NOMINAL EXCHANGE RATES IN THE SHORT AND LONG TERM: 1973-2006

\section{A. Log changes in the nominal exchange rates}

$\%(\mathrm{GBP} / \mathrm{USD})$

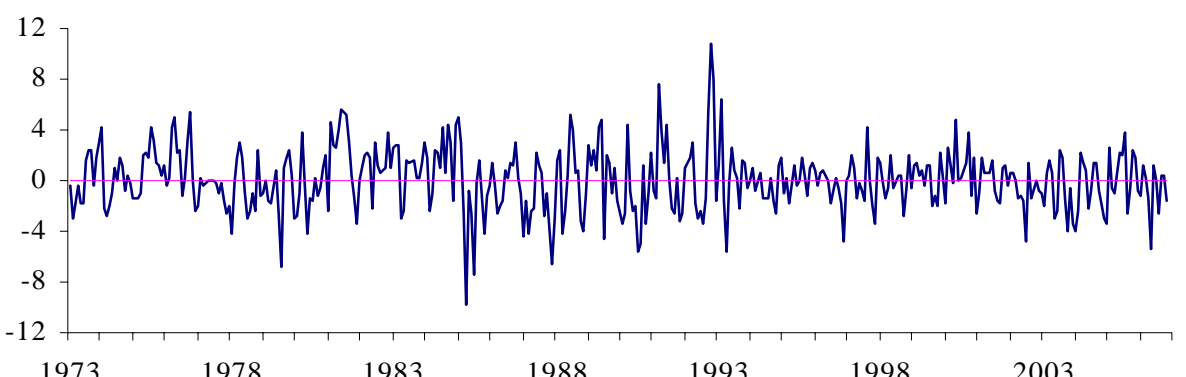

$\%(\mathrm{DEM} / \mathrm{USD})$

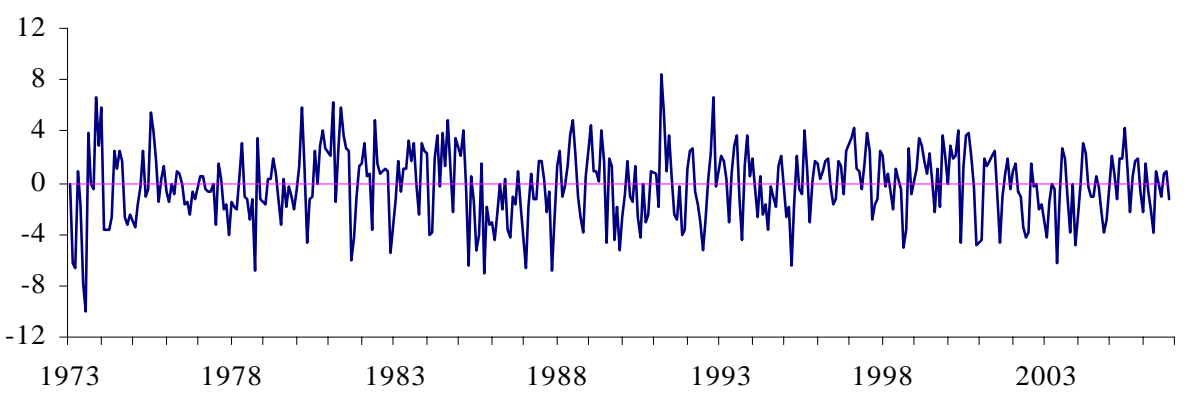

$\%($ JPY/USD)

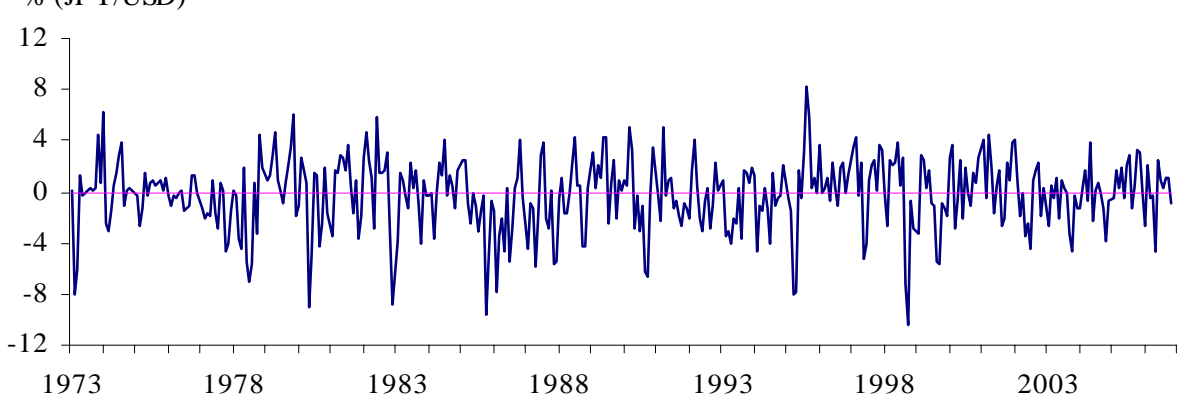

B. Nominal exchange rates and relative prices
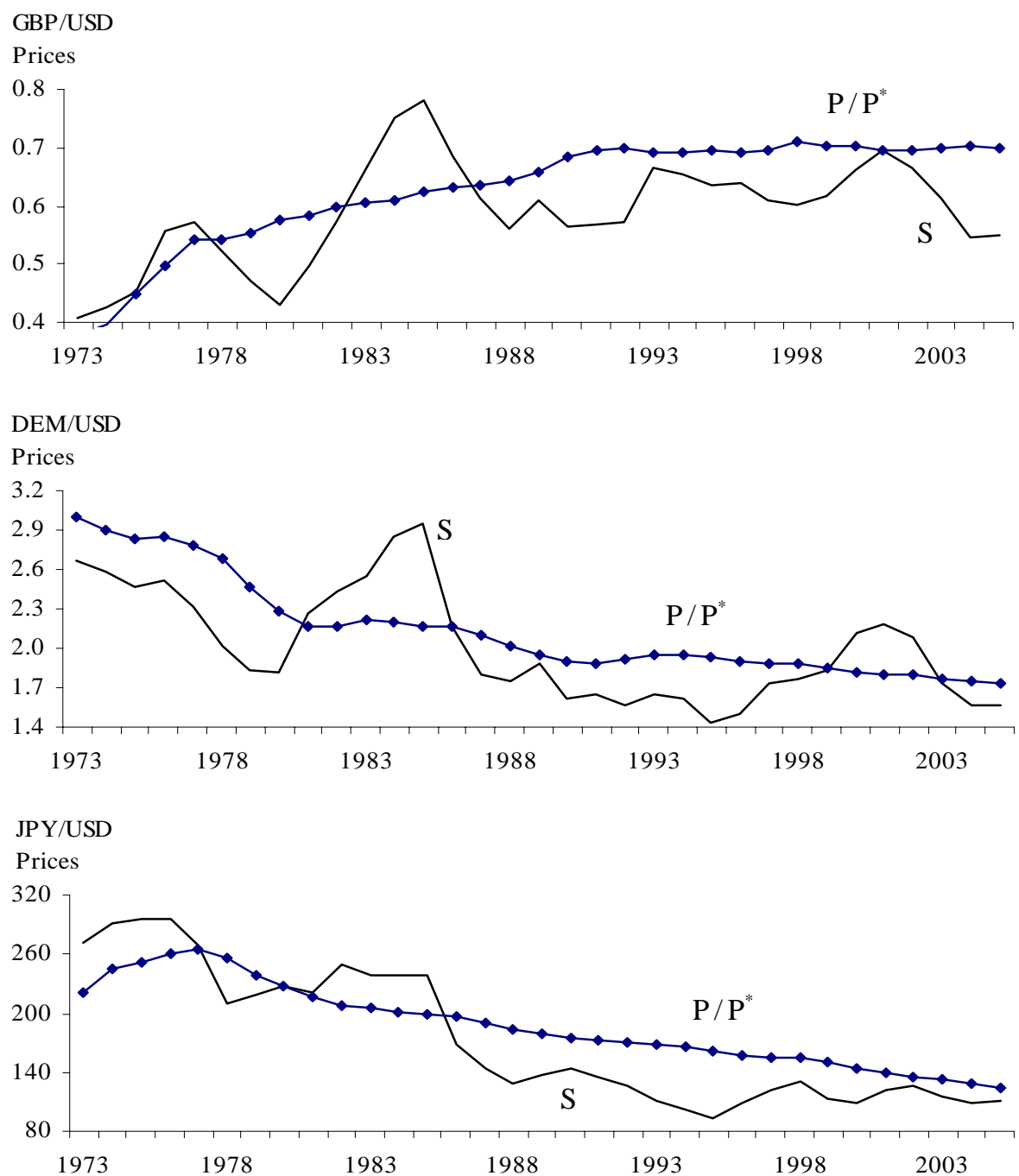

Source: International Monetary Fund International Financial Statistics, and Pacific Exchange Rate Service (http://pacific.commerce.ubc.ca/xr/data.html).

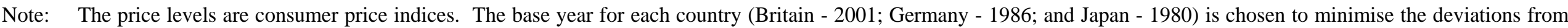
parity, $\mathrm{S}-\mathrm{P} / \mathrm{P}^{*}$. This amounts to assuming that PPP holds on average over the 33 years, and determines nothing more than the "average" height of the relative price curve. 
FIGURE 2

THE DEHEGING OF GOLD

Indicator (million ounces)

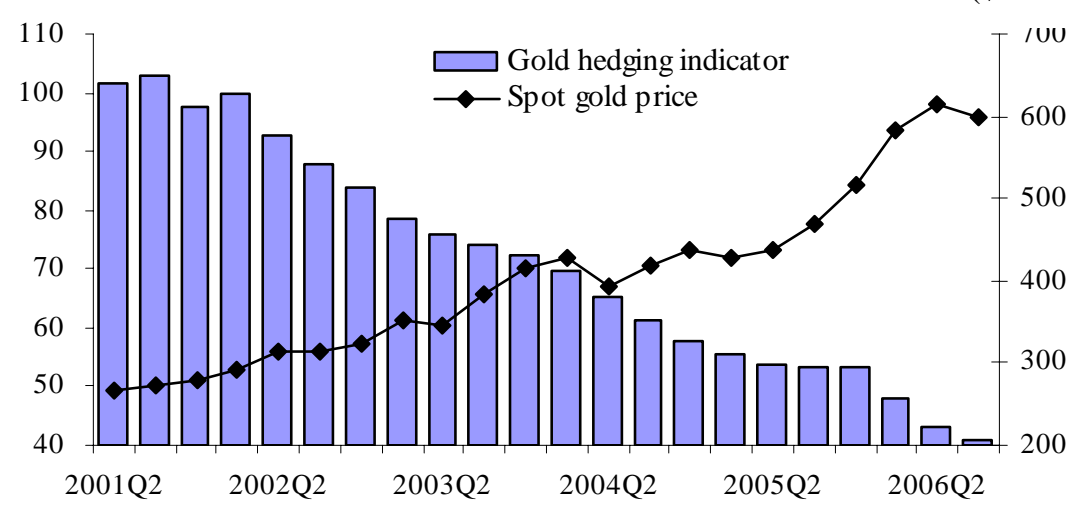

Source: Mitsui Global Precious Metals, Virtual Metals and Haliburton Mineral Services (2006).

FIGURE 3

THE QUANTITY THEORY OF MONEY

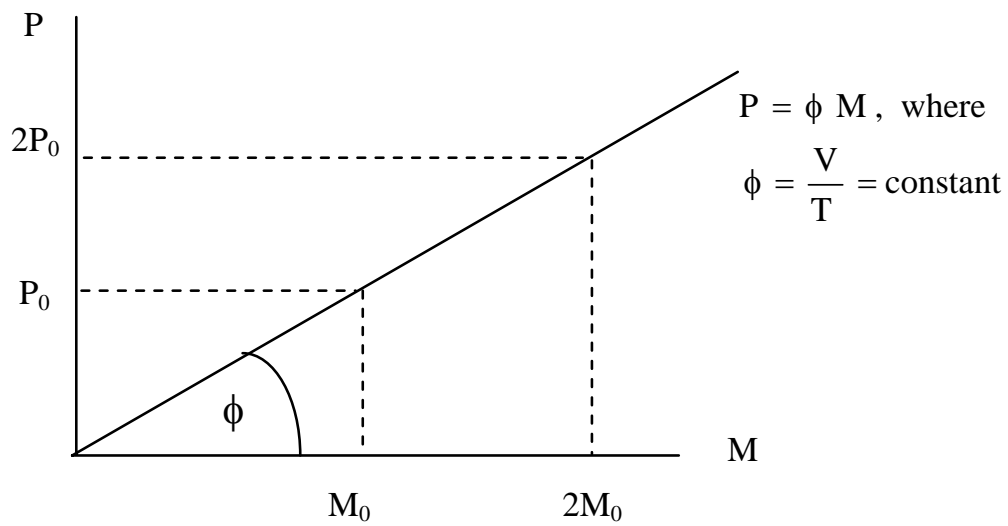

FIGURE 4

MONEY AND THE REAL ECONOMY

$\mathrm{P}_{\mathrm{T}}$

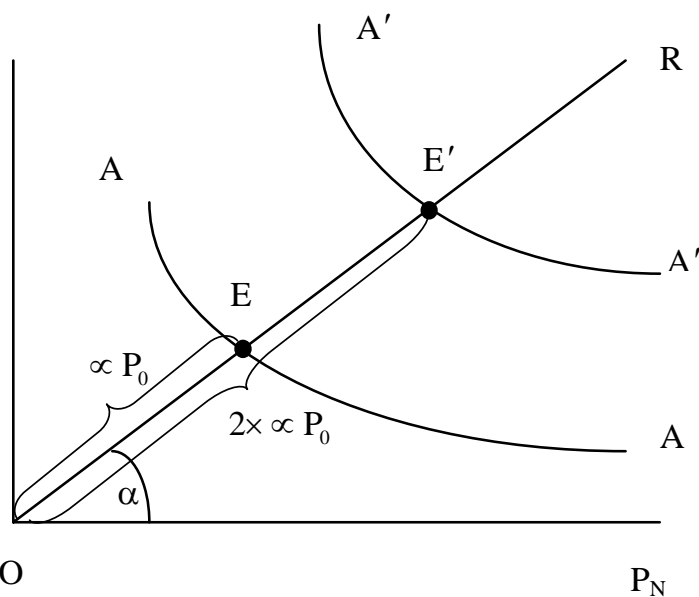


FIGURE 5

PRICES AND THE EXCHANGE RATE

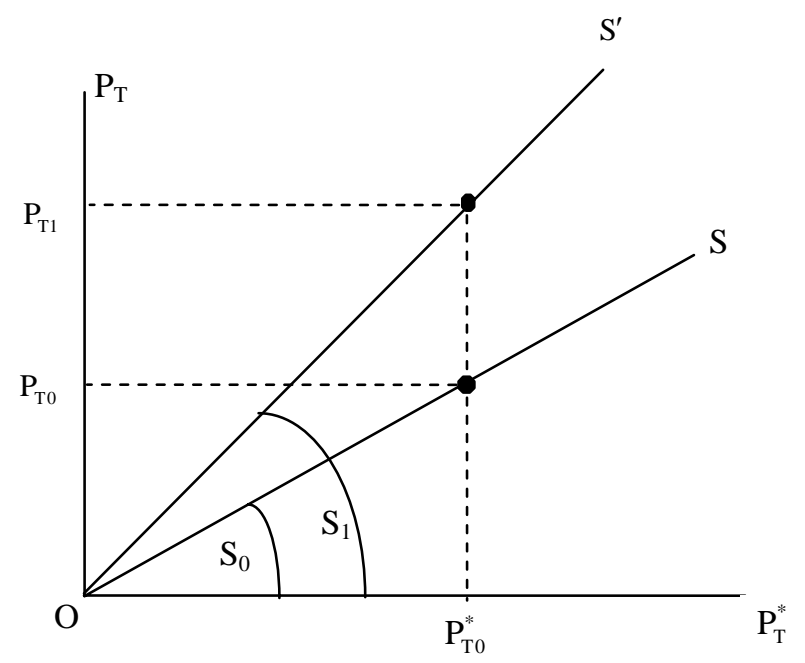

FIGURE 6

PRICES AND THE EXCHANGE RATE

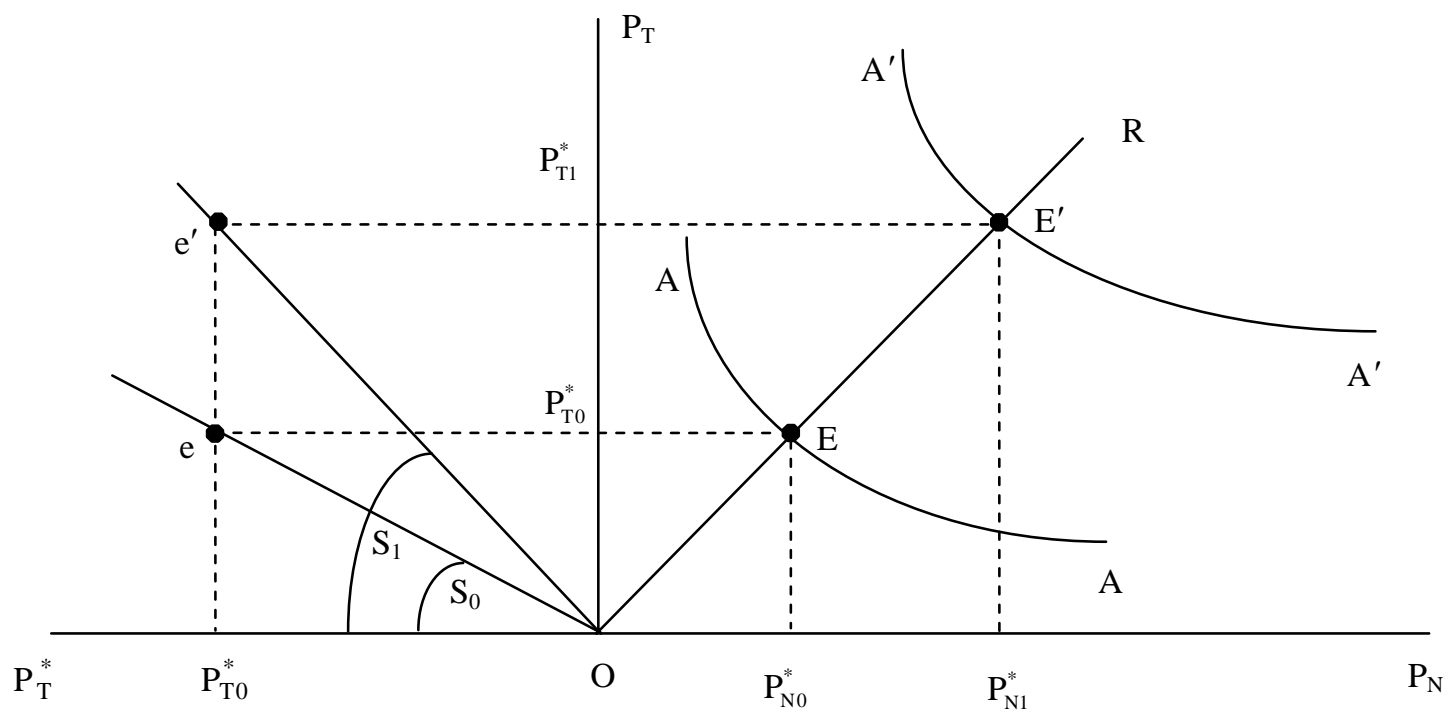


FIGURE 7

MONEY, PRICES AND THE EXCHANGE RATE

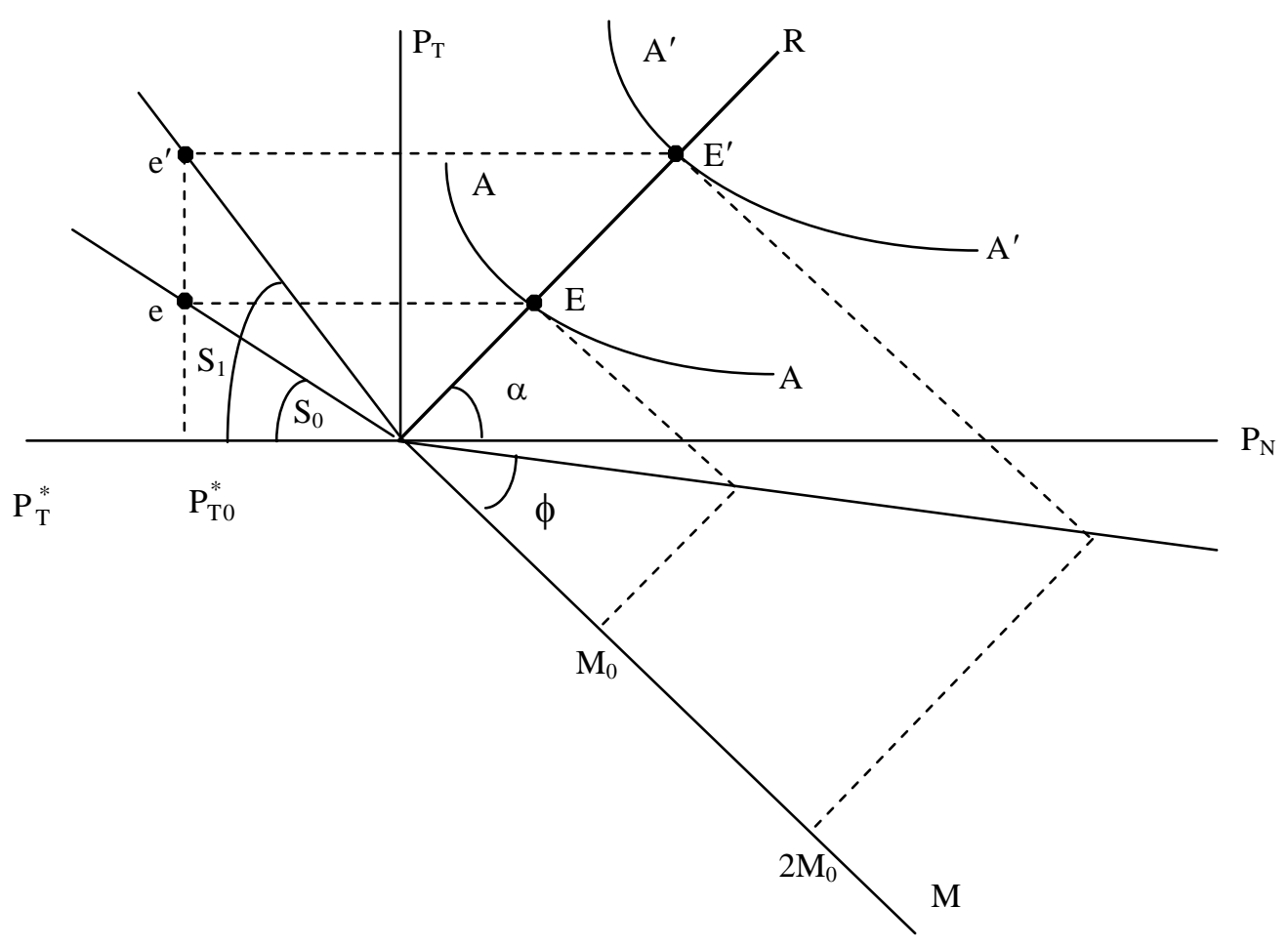

FIGURE 8

STICKY PRICES AND THE EXCHANGE RATE

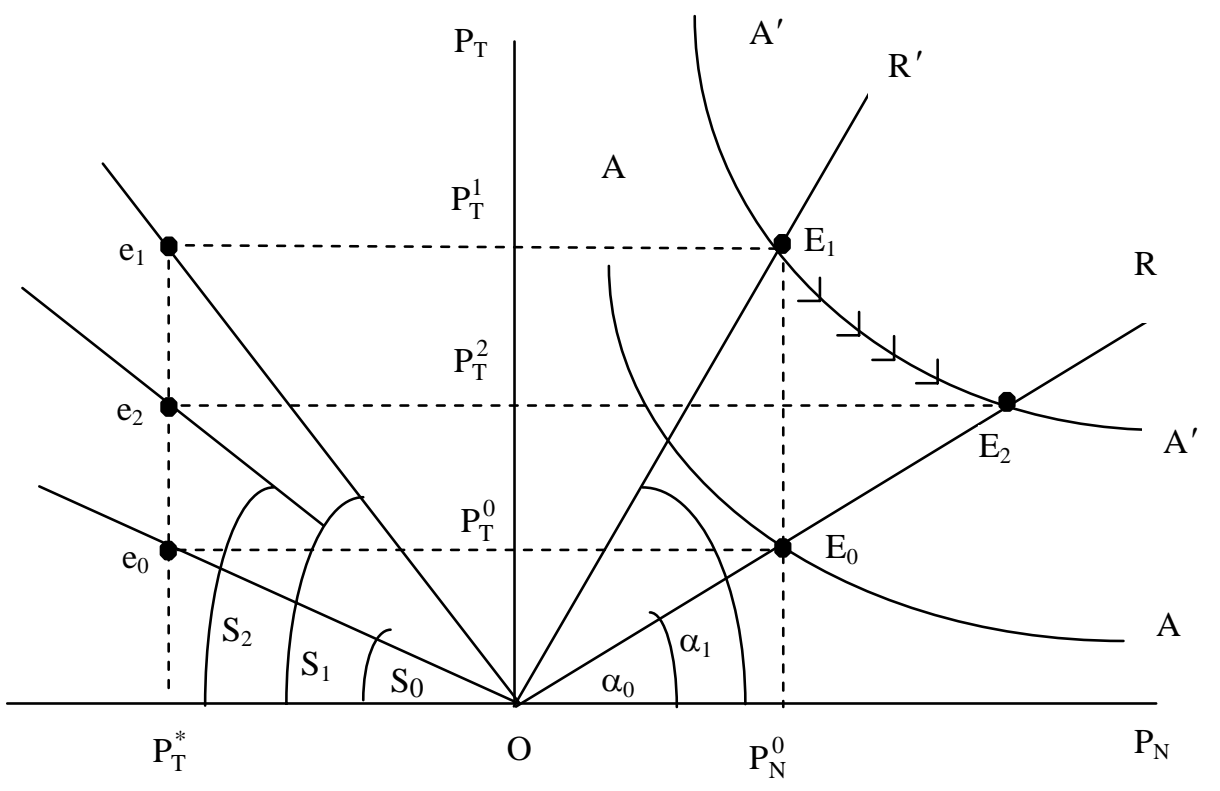


FIGURE 9

\section{EXCHANGE-RATE OVERSHOOTING}

A. The nominal rate

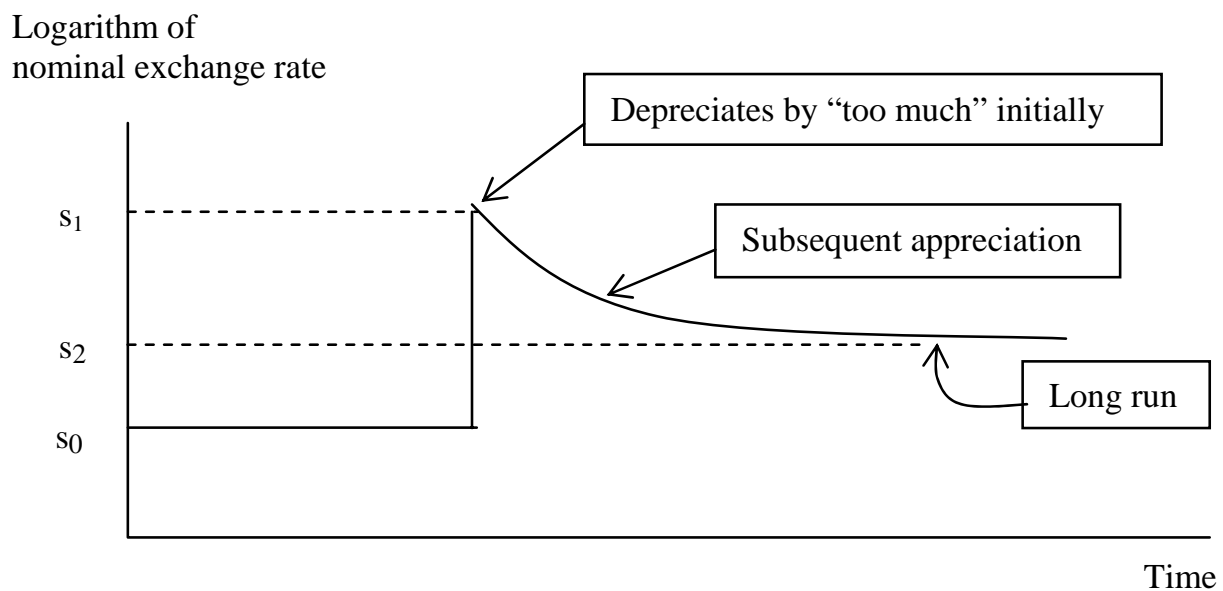

B. The real rate

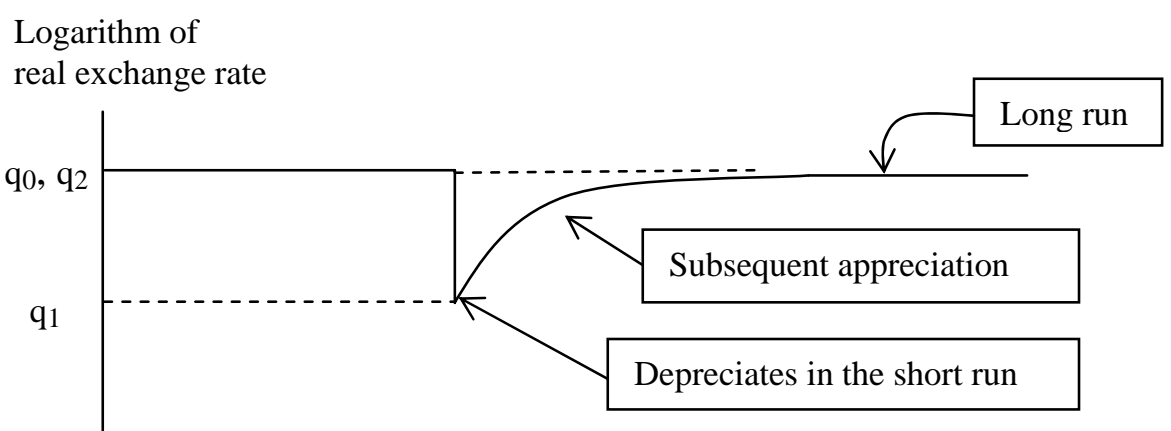

Time 
FIGURE 10

CHANGES IN EXCHANGE RATES AND RELATIVE PRICES,

50 COUNTRIES, 1974-2004

(Annualised logarithmic changes)

A. Short run

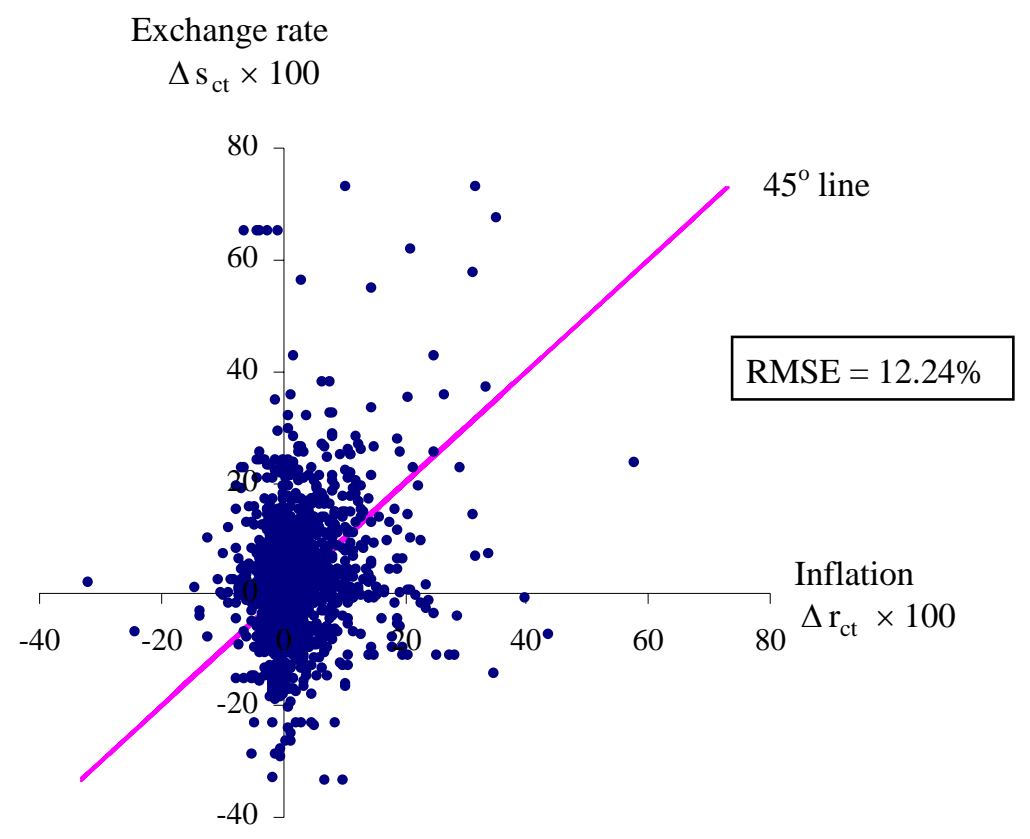

B. Long run

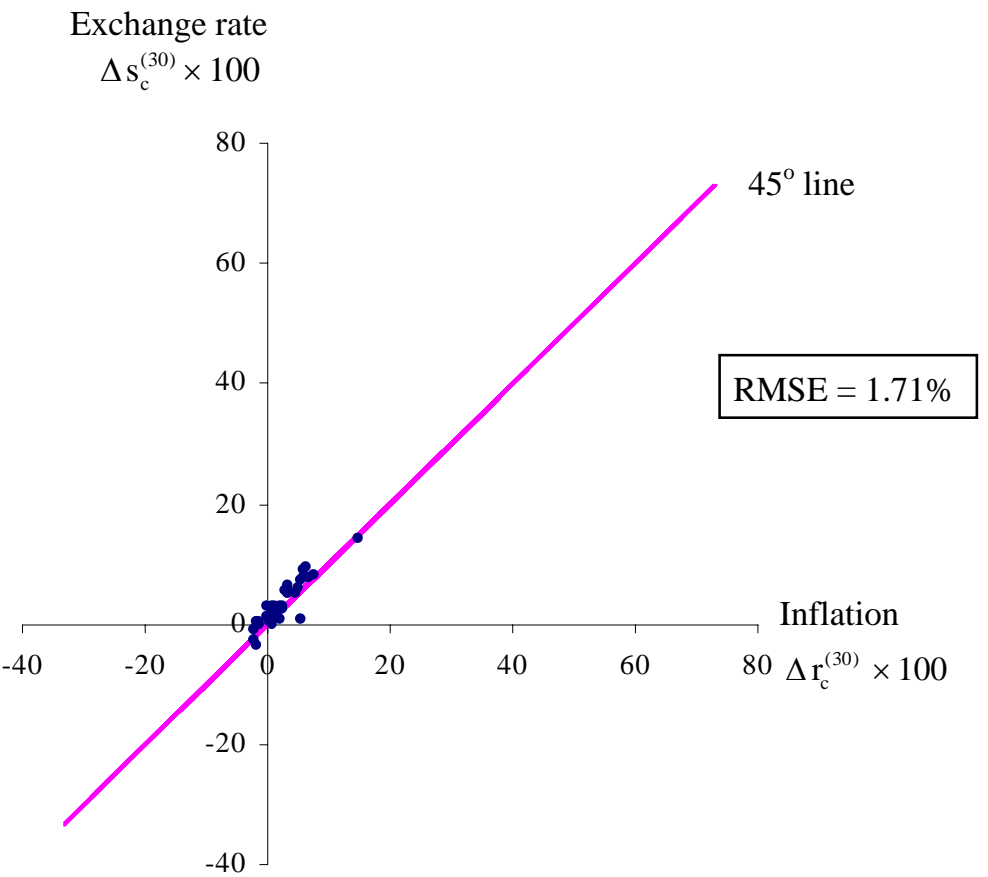

Note: There are 58 countries in Panel A and 38 countries in panel B due to missing observations, which mainly associated with EU countries. 
FIGURE 11

VARIANCES OF EXCHANGE RATES AND RELATIVE PRICES

Ratio of

variances $\phi(\mathrm{m})$

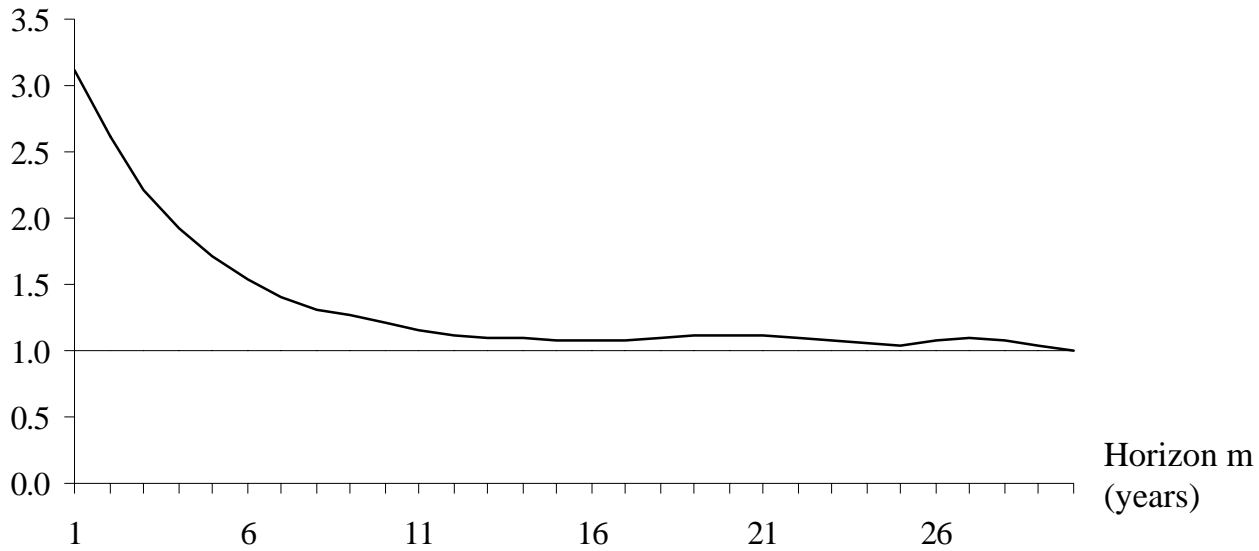

FIGURE 12

EXCHANGE RATES AND PRODUCTIVITY

A. Rich country

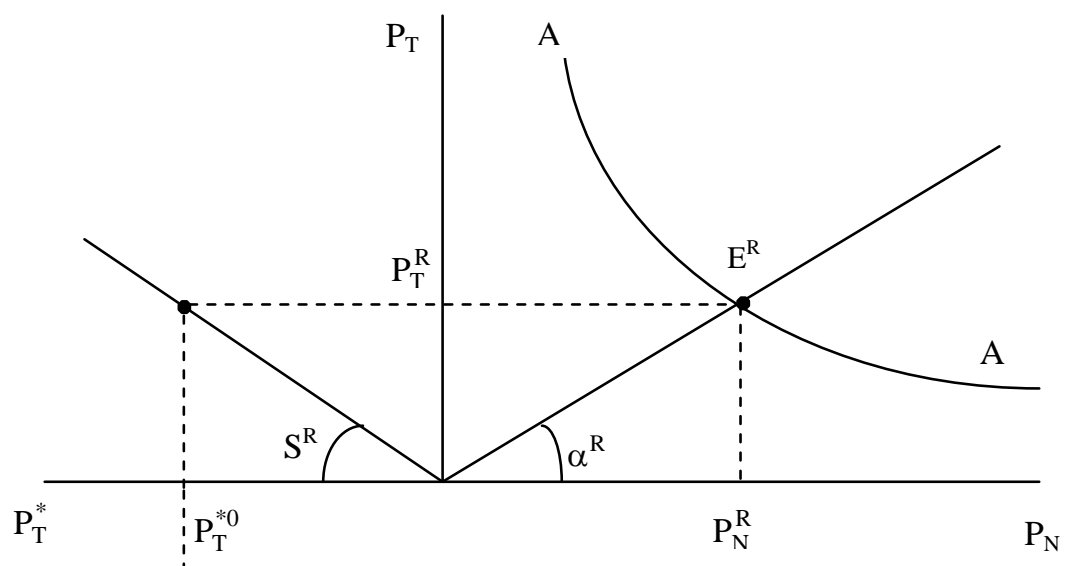

B. Poor country

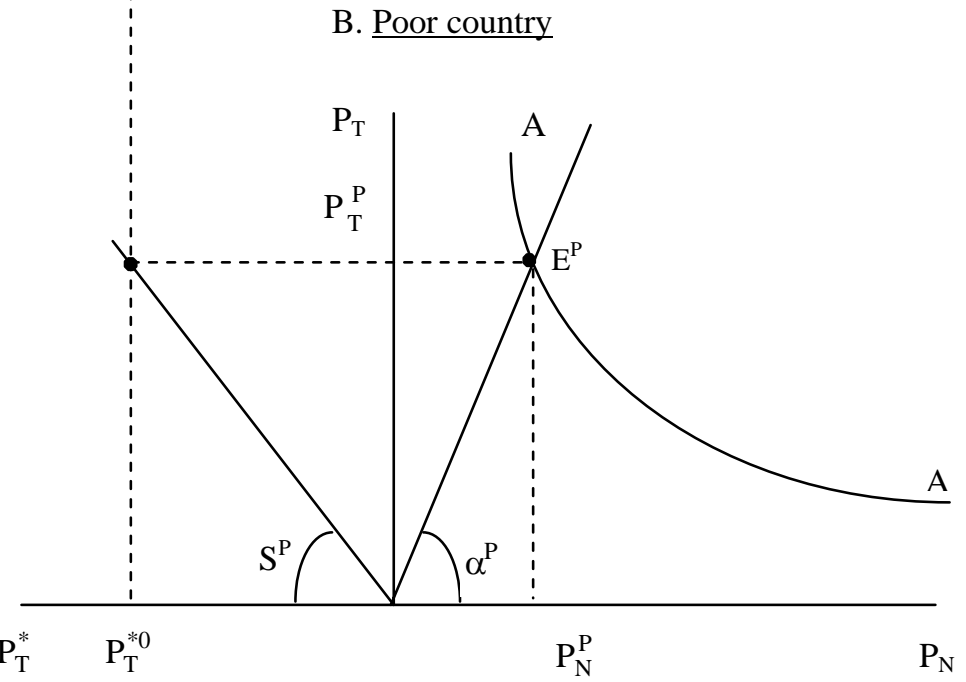


FIGURE 13

TWO MEASURES OF INCOME IN 77 COUNTRIES, 1992

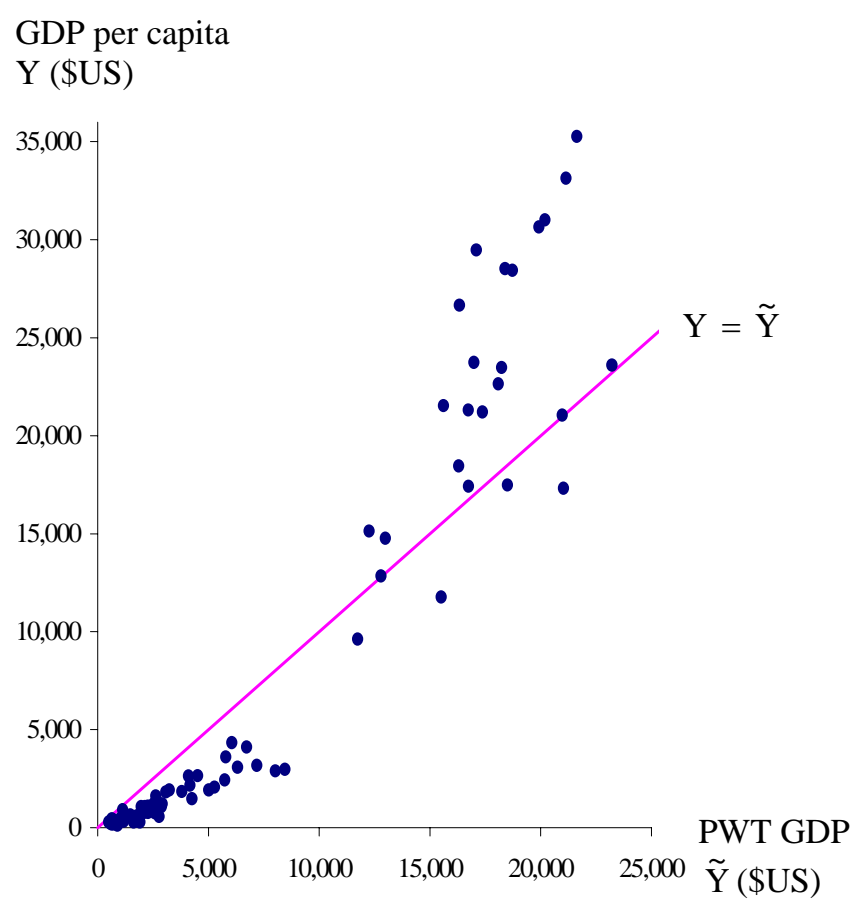

FIGURE 14

THE EFFECTS OF A BOOMING EXPORT SECTOR

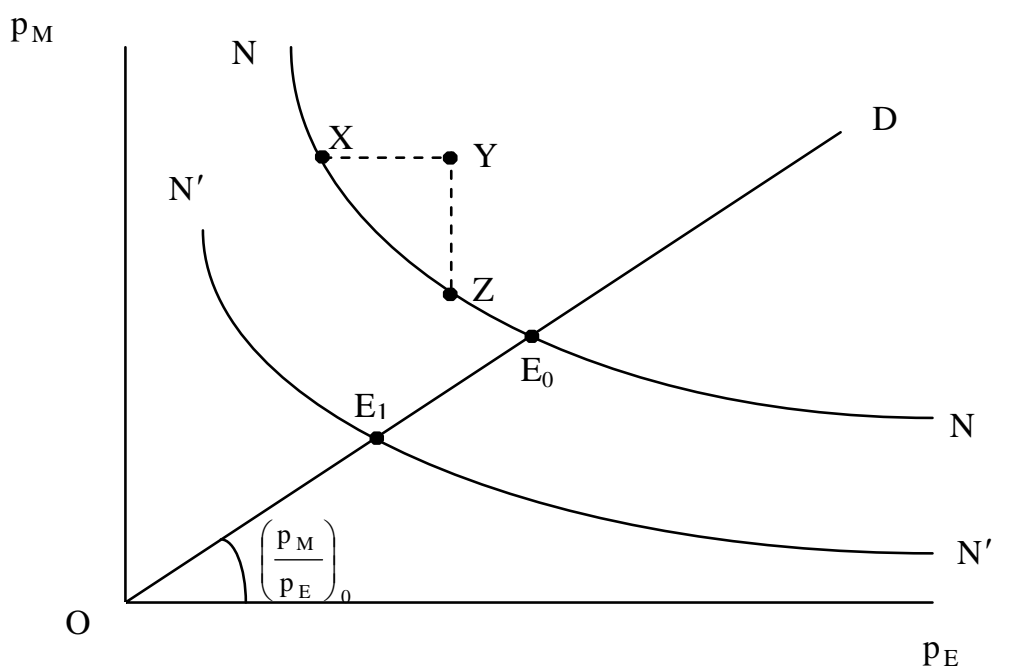


FIGURE 15

MORE ON THE EFFECTS OF A BOOMING EXPORT SECTOR

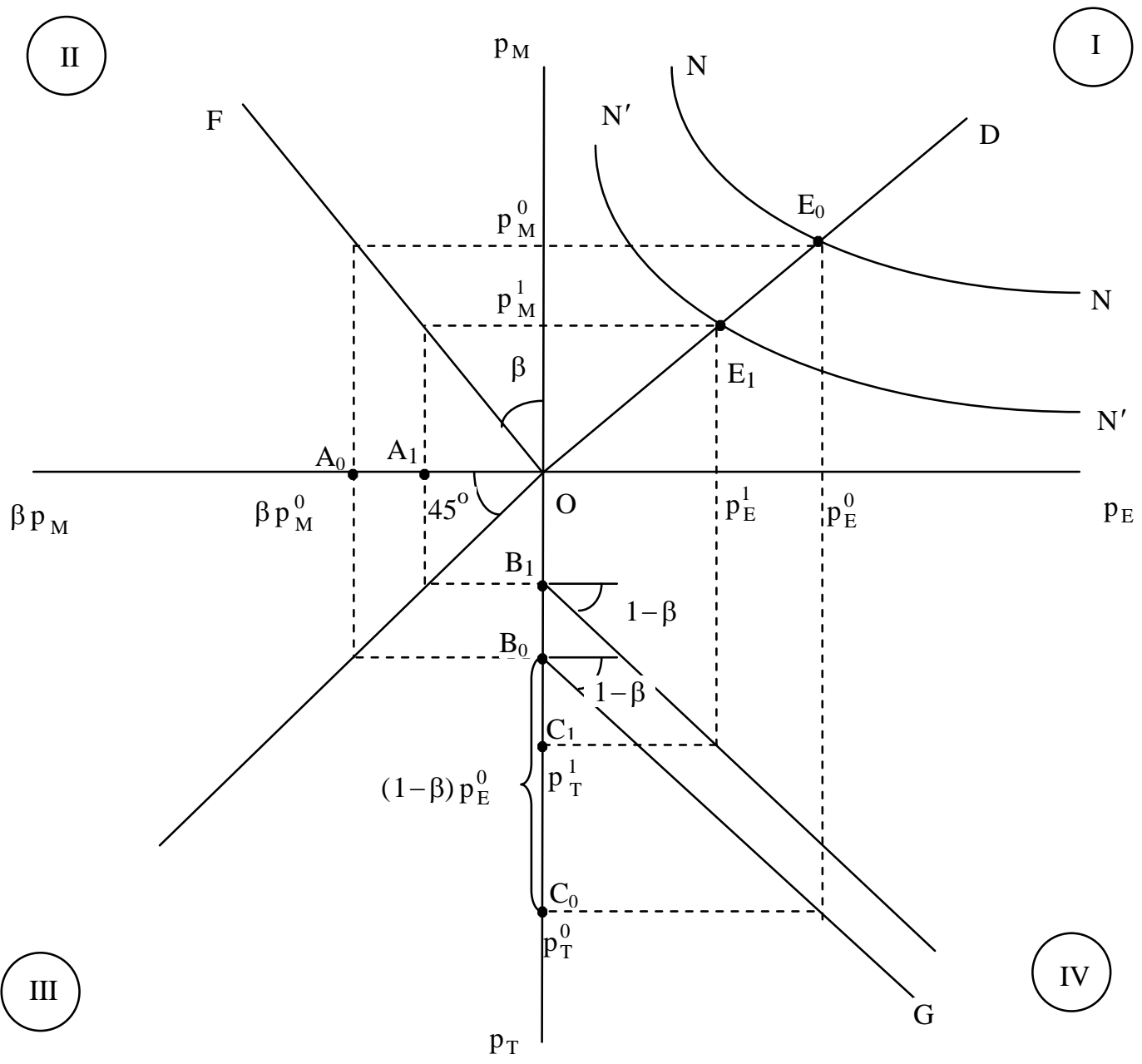

TABLE 1

RESPONSE OF EXCHANGE RATES TO VARIOUS SHOCKS

\begin{tabular}{|c|c|c|c|}
\hline & \multirow[b]{2}{*}{ Shock } & \multicolumn{2}{|c|}{ Exchange rate } \\
\hline & & Nominal & Real \\
\hline \multirow[t]{3}{*}{1.} & Monetary expansion with & & \\
\hline & - flexible prices & Depreciation & No change \\
\hline & - sticky prices & $\begin{array}{l}\text { Initial depreciation and partial } \\
\text { appreciation subsequently } \\
\text { (overshooting) }\end{array}$ & $\begin{array}{l}\text { Initial depreciation and subsequent } \\
\text { appreciation, but no change in the } \\
\text { long run }\end{array}$ \\
\hline 2. & $\begin{array}{l}\text { Increase in relative price of traded } \\
\text { goods (productivity bias) }\end{array}$ & Depreciation & Depreciation \\
\hline 3. & A booming sector & Appreciation & Appreciation \\
\hline
\end{tabular}

